\title{
HOMMAGE

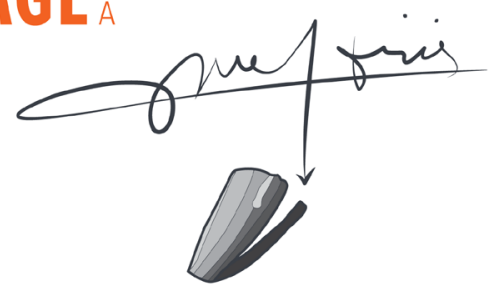

\section{Technological features in the late Middle Paleolithic of the Côte Chalonnaise (Burgundy, France)}

\author{
Klaus Herkert ${ }^{1}$, Jens Axel Frick ${ }^{2}$ \\ ${ }^{1}$ Department of Early Prehistory and Quaternary Ecology, Institute of Prehistory, Early History and Medieval Archeology, Eberhard Karls Uni- \\ versity of Tübingen, Schloss Hohentübingen, Burgsteige 11, 72070 Tübingen, Germany \\ ${ }^{2}$ Corresponding author. Projet collectif de recherche (PCR) "Le Paléolithique supérieur ancien en Bourgogne méridionale" associated with \\ UMR 6298 ARTeHIS at the Université de Bourgogne, Dijon, France. \\ Email: jens-axel.frick@ifu.uni-tuebingen.de
}

\section{Abstract}

Kivonat

Keywords

\section{Kulcsszavak}

Cite as - hivatkozás

\section{Article history Kézirat történet}

Copyright $\cdot$ Jogok ()ㅇㅇㅛ
While former typological studies drew a heterogeneous image for the Middle Paleolithic record of the Côte Chalonnaise region in southern Burgundy (France), recent research, re-evaluation of old collections, and comparative analysis from several Middle Paleolithic sites in the area were able to highlight a homogeneous pattern of litho-technological features. The assemblages have been evaluated according to their general composition, the identifiable reduction concepts as well as their bifacial component. The concurrent results allow us to hypothesize a regional site cluster based on Levallois reduction and a common occurrence of Keilmesser (with tranchet blow). In chronological terms, dating attempts on stratified material from Grotte de la Verpillière I and II suggest a late Middle Paleolithic age of the sites around the end of MIS 4 or the beginning of MIS 3.

\section{A Côte Chalonnaise régió (Burgundia, Franciaország) késő középső paleolitikumának technológiai jellemzői}

A korábbi tipológiai vizsgálatok heterogén képet vázoltak fel a dél-burgundiai Côte Chalonnaise régió (Franciaország) középső paleolit leletanyagáról. Az újabb kutatások azonban a kőpattintási technológiai jellemzők homogenitását mutatták ki korábbi gyưjtemények revíziója, illetve középső paleolit lelőhelyek összehasonlító vizsgálata segítségével. A leletanyagokat általános összetételük, azonosított magkőredukciós koncepcióik, illetve a bifaciális darabok alapján értékelték. Az egybehangzó eredmények nyomán, a Levallois redukció és a tranchet blow technikával kialakított, Keilmesser típusú eszközök jelenléte alapján egy regionális megtelepedési csoportot feltételezünk. Az időrendet illetően, a Grotte de la Verpillière I és II rétegzett lelőhelyek datálási kísérletei a késői középső paleolitikumra, a MIS 4 végére vagy a MIS 3 kezdetére datálják ezt a csoportot.

Late Middle Paleolithic, eastern France, Levallois, bifacial elements, Keilmesser

késô középsố paleolitikum, Kelet-Franciaország, Levallois, bifaciális eszközök, Keilmesser

Herkert, K., \& Frick, J. A. (2019-2020). Technological features in the late Middle Paleolithic of the Côte Chalonnaise (Burgundy, France). Litikum, 7-8 (Studies commemorating Jacques Tixier), 35-54. https://doi.org/10.23898/ litikuma0024

Received | Érkezés: 2020. 03. 11. Accepted | Elfogadás: 2020. 03. 14. Published | Közzététel: 2020. 12. 30.

This is an open-access article distributed under the terms of the Creative Commons Attribution License, which permits unrestricted use, distribution, and reproduction in any medium, provided the original author and source are credited. | Ez egy nyílt hozzáférésű publikáció, amit a Creative Commons 4.0 licensze véd. A termék szabadon használható, terjeszthető és sokszorosítható az eredeti szerző és forrás megjelölése mellett. 


\section{Introduction}

The Paleolithic record in southern Burgundy is very dense, particularly for the Middle Paleolithic period. According to the DRAC's database (Fr. Directions régionales des affaires culturelles, cultural heritage of Bourgogne-Franche-Comté), there are 212 records in southern Burgundy (i.e. Saôneet-Loire department), including large open-air sites but also caves and rock shelters or dispersed single find spots (Fig. 1).

Paleolithic research has a long-lasting tradition in the region since the first excavations in the 1860s at sites like Solutré (Arcelin 1872), the Grotte de Germolles or de la Verpillière (Méray 1869) (now Grotte de la Verpillière I) or at Grotte de la Mère Grand (Combier 1956-1957). However, except for a few attempts (eg. Farizy 1995b; Gouédo 1999), no comprehensive comparative analysis of the assemblages took place. This absence may result from assemblages that are often decontextualized (e.g., lacking dates, sequence, or spatial data, see Frick 2016b; or Mackay et al. 2014), deriving either from old excavations with little or no recorded stratigraphical information or from surface collections (assigned vaugely to single locations without exact position data).

The lithic assemblage from stratified material from Grotte de la Verpillière II at Germolles, discovered in 2006 and excavated from 2006 to 2017, and its subsequent analysis (Frick 2016a; 2016b; Frick, Floss 2017), now provide a strong basis for further investigation and the assemblage serves as reference assemblage for the region.

The detailed analysis of the Verpillière II material, especially concerning the rich assemblage of horizon 3 (GH 3), provides first insights into a stratified Middle Paleolithic assemblage under modern excavation and research conditions for the southern Burgundy region in decades and reveals important data in terms of assemblage composition, site organization or litho-technological characteristics. Radiometric dating (IRSL, AMS 14C, and ESR/U-Th) places the GH 3 material from Verpillière II into a late Middle Paleolithic context between the end of MIS 4 and the beginning of MIS 3 (Heckel et al. 2016; Richard et al. 2016; Zöller, Schmidt 2016). In addition to excavation work, an intense re-examination of the available collections of major neighboring sites was and is still being conducted. This now allows a comparative view of the region's Middle Paleolithic record.

In contrast to previous work, which was based on typological criteria and thus suggested heterogeneous patterns of assignment, a fairly homogeneous picture of the assemblages can be drawn when technological criteria are used.

The recently re-investigated sites, including the Grottes de la Verpillière I and II in Germolles, La Roche in Saint-Martin-sous-Montaigu, Rue Cataux in Chenôves and La Clôsure in Bissy-sur-Fley will now be briefly introduced (Fig. 1). Then, an overview of our quantitative and technological comparative research, which favors the hypothesis of a linked Middle Paleolithic regional site cluster, is given.

\section{Presentation of the sites}

The following data of the assemblages are mainly based on our research (analysis of recent excavations and re-examination of old collections). To extract the Middle Paleolithic component from decontextualized assemblages, techno-typological criteria have been applied. If not indicated otherwise, we refer to material stored in the Musée Denon at Chalon-sur-Saône. In some cases, material from private collections has also been included in the analysis. In addition, a brief presentation of the sites and their Middle Paleolithic component concentrates on technologically and typologically relevant pieces, i.e., bifacially worked artifacts, and those revealing reduction concepts.

\subsection{Grotte de la Verpillière I}

The Grotte de la Verpillière I site in Germolles was first excavated in 1868 (Méray 1869; 1876). Since then, a multitude of test-pits and excavations were conducted at the site during the 19th and 20th centuries (Dutkiewicz 2011; Dutkiewicz, Floss 2015). The most recent activities have been undertaken between 2006 and 2016 (e.g., Floss 2007; Floss et al. 2013b; Floss et al. 2016). Nowadays, the site appears as a rock shelter with huge collapsed blocks in the entrance, which collapsed after the Paleolithic settlement. In addition to the well-known Middle Paleolithic lithic assemblage component (Desbrosse et al. 1976; Frick 2010; Frick, Floss 2017; Frick et al. 2017, 2018), the site yielded artifacts from the Châtelperronian (Floss et al. 2017; Würschem 2015), the Aurignacian (Floss et al. 2015) and, to a lesser extent, the Gravettian (Floss et al. 2013a), the Neolithic and Medieval times. The total lithic assemblage of the site is well over 20,000 lithics.

The assemblage to be assigned to the Middle Paleolithic has not yet been conclusively analyzed. However, we have reliable data on the assemblages from the old excavations below the rock shelter and on the forecourt (Dutkiewicz 2011; Frick 2010) and the GH 16 below the rock shelter (Litzenberg 2015). Within the lithic industry, which is dominated by Levallois reduction, we note an important number of bifacial objects like Keilmesser (hereafter: Keilmesser) with tranchet blow and corresponding blanks and a huge variety of other bifacial forms (Frick, Floss 2017). If the bifacial pieces of all known activities are combined, we arrive at a stock of $n=121$ pieces. Among them, there are $n=13$ asymmetric bifaces with small back, $n=2$ bifacially worked objects, $n=10$ double symmetric bifaces, $n=5$ small bifaces (Fäustel), $n=16$ bifacial Keilmesser without tranchet blow, $n=40$ bifacial Keilmesser with tranchet blow, as well as $n=3$ bifacial Keilmesser with a failed tranchet blow, one bifacial scraper with a tranchet blow and $n=31$ preforms of bifacial objects.

Blank production is dominated by Levallois, followed by opportunistic blank production, as will become evident for the surrounding sites, too. Other elaborate reduction concepts, such as Discoidal or Quina, are massively underrepresented. The tools are characterized by different side scraper variants, which are produced on different kinds of blanks (cortical, configuration, and target blanks). 

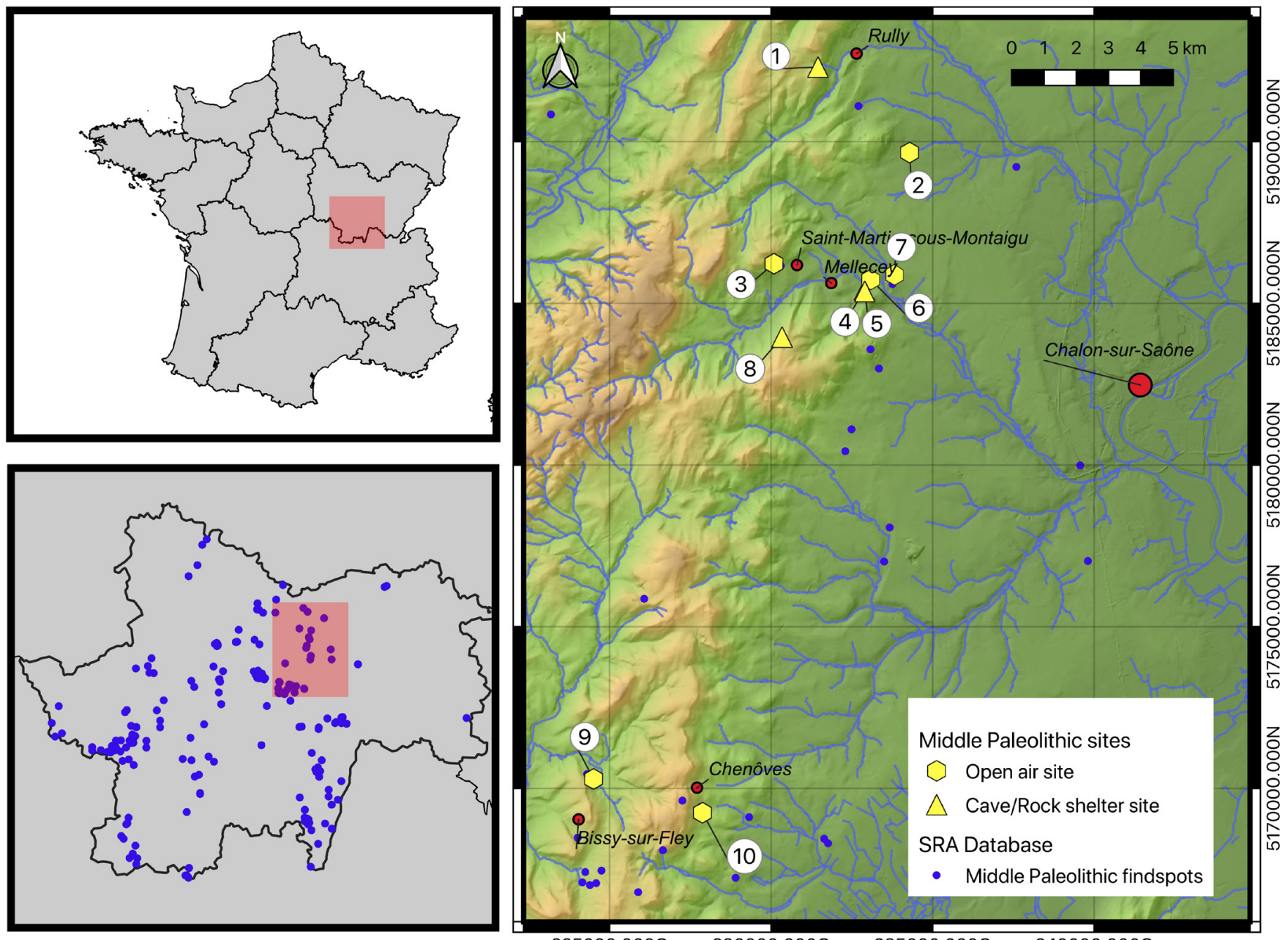

625000.0000

630000.0000

635000.0000

640000.0000

Figure 1. Upper left: Schematic map of France with location of the Saône-et-Loire department (red rectangle). Lower left: Saôneet-Loire department with its Middle Paleolithic record (blue dots) according to the DRAC-Bourgogne-Franche-Comté database and location of the Côte Chalonnaise research area (red rectangle). Right: Map of the Côte Chalonnaise research area with Middle Paleolithic record (blue dots) according to DRAC-Bourgogne-Franche-Comté database and important sites mentioned in the text: 1) Grotte de la Mère Grand in Rully; 2) Les Griffières in Fontaines; 3) La Roche in Saint-Martin-sous-Montaigu; 4) Grotte de la Verpillière I in Germolles; 5) Grotte de la Verpillière II in Germolles; 6) Saint-Sulpice in Germolles; 7) En Roche in Germolles; 8) Grotte des TeuxBlancs in Saint-Denis-de-Vaux; 9) La Clôsure in Bissy-sur-Fley; 10) La Rue Cataux in Chenôves. (Mapping: Herkert, topographic data: IGN France)

\subsection{Grotte de la Verpillière II}

The Grotte de la Verpillière II, discovered in 2006, about 50 $\mathrm{m}$ south of Grotte de la Verpillière I, was excavated by Floss between 2006 and 2017 (eg. Floss 2008; 2009a; 2009b; Floss et al. 2013c; Floss et al. 2016). So far, it is the only multilayered Middle Paleolithic site excavated under modern conditions in southern Burgundy. The excavated material is not as extensive as from the neighboring Grotte de la Verpillière I. However, the material from GH 3, 4x, and 4 was within an intact stratigraphy and allows correlations. Today, the site consists of a cave tunnel and a corresponding collapsed rock shelter. The excavation took place at the entrance of the cave tunnel. At the end of the excavation, GH 3 yielded $n=4,247$ lithics, GH $4 \mathrm{x}$ consists of $n=27$ lithics and GH 4 yielded $n=413$ lithic objects.

All three layers are dominated by Levallois reduction and yielded a huge variety of bifacial objects (including
Keilmesser with tranchet blow, but there were no double symmetrical bifaces). From GH3, there are $n=4$ asymmetrical bifaces with a restricted back, $n=5$ bifacially worked objects, $n=3$ small bifaces (Fäustel), $n=4$ Keilmesser without tranchet blow, $n=3$ Keilmesser with tranchet blow, $n=11$ preforms of bifacial objects, and $n=9$ blanks of tranchet blow.

Other blank reduction concepts appear only in minor quantities, but there is a significant amount of opportunistic reduction. Ventral reduction on blanks was also used for Levallois core configuration. Blades are only incidentally present. Tools were mainly made on blanks (cortical, configuration, and target blanks), but cores were also retouched to tools. All three GHs yielded $n=483$ retouched objects, including side scrapers, objects with simple retouch, objects with multiple retouched parts or retouched points, whereas $n=111$ retouched objects are connected to Levallois reduction. On the one hand, $n=73$ of the retouched pieces are tool tips and clearly show that these pieces were used at this place 
and are broken. On the other hand, there are hafting rests, mostly basal fragments that were laterally retouched or show small fractures and most likely were sitting in the haft and were replaced on-site (retooling). Bulb reduction of tools on blanks is a common method for flattening and easier hafting of the pieces. Groszaki, dorsal reduction, and Janus flakes are present on a small scale. There are hardly any "Upper Paleolithic" tool types. The chronometric data from IRSL, ESR/UTh and AMS 14C (Heckel et al. 2016; Richard et al. 2016; Zöller, Schmidt 2016) available so far indicate a late Middle Paleolithic context at the end of MIS 4 or beginning MIS 3 (Frick 2016b; Frick, Floss 2017).

\subsection{La Roche}

The La Roche open-air site appears in the literature with various names, e.g., Vignes de la Roche, Vignes du Gros Theu, or Les vignes blanches (Armand-Calliat 1928; Combier 1962). These names refer to the prominent rock above the vineyards where the site is located. In 1896, the first surface collections were made by Pierre (Jacquin 1896). However, it was not until 1926 that Lènez carried out systematic surveys and a test-pit excavation (Guillard 1947; Lènez 1926). From the 1950s onwards, Gros conducted numerous surveys (Gros 1964; Gros, Gros 2005). Since 2002, Donguy is conducting surveys and in the years 2009 and 2014, surveys were carried out by Floss's working group (Herkert 2014). There is no information of any further excavation at this site yet. The collection of Lènez was the subject of a master's thesis (Pouliquen 1982; 1983). All the site's known material is currently being analyzed and processed by Herkert (2020). To date, after intensive reevaluation of the known collections (Musée Denon and private ones), we know of about 1,800 lithic artifacts that can be associated with the Middle Paleolithic, wherein the Denon material comprises $n=1,250$ pieces. Of the $n=66$ cores from all the material, $n=62$ have been reduced according to the Levallois concept. So far, the Denon material alone provides a huge variety of $n=145$ bifacial objects, including $n=93$ bifaces as well as bifacial points and various bifacially worked objects, one of which shows a tranchet blow modification, $n=10$ Keilmesser without tranchet blow, $n=9$ Keilmesser with tranchet blow, $n=21$ bifacial side-scrapers, six of which also show a tranchet blow, $n=3$ bifacial pieces with failed tranchet blow, $n=9$ preforms and $n=6$ blanks of tranchet blow.

As over 600 pieces from the analyzed material can be associated with Levallois reduction, Levallois appears to be the main reduction concept, while the degree of other reduction concepts is quite low. The ventral reduction on blanks for the configuration of Levallois cores is visible. There is no noticeable blank selection for the manufacture of tools. Tools are made on a huge variety of blank types (cortical, configuration, and target blanks). Also, bulb reduction and other hafting evidence appear on tools.

\subsection{Rue Cataux}

The site was discovered by E. Guillard in 1934 near Chenôves, but he only published it 26 years later (Guillard 1960). Gros collected further surface finds in the 1950s and 1960s (Gros, Gros 2005). The spelling of the site varies between Cataux,
Cateux, and Catoux, and sometimes even station du Carrouge is possible. In 1962, in a geological section caused by road construction, Gros recognized a clay layer separating two layers of pebbles containing finds (Gros, Gros 2005). But, as far as we know, no further excavations were carried out. Over 450 finds from the three surface collections (coll. Guillard, Salis, and Gros) of the site in Musée Denon can be assigned to the Middle Paleolithic.

The bifacial objects include $n=7$ Keilmesser, two of which were modified with a tranchet blow and two others show a failed attempt of a tranchet blow modification. Furthermore, there are $n=20$ bifacial pieces, at least one of which also shows a tranchet blow. In addition, $n=1$ blank of tranchet blow is present.

The assemblage from Rue Cataux fits into the morphological and technological habitus of the previous examples. In addition to Keilmesser with tranchet blow, high variability of the bifacial objects can also be observed. Levallois reduction occupies a leading position over other reduction concepts. Also, in these assemblages, blades occur only incidentally. Tools are made on cortical, configuration, and target blanks and are dominated by side scrapers, but points (retouched or not) are also important.

\subsection{La Clôsure}

The open-air site of La Clôsure (also La Clauzure or la Closure) near Bissy-sur-Fley was discovered by Méray in the 1870s (Parriat 1956). Its topological setting resembles that of La Roche in Saint-Martin-sous-Montaigu. Several collections exist from the site. The finds stored in the Musée Denon presumably come from various collection activities (based on what is written on the boxes), but it is not possible to determine exactly who collected them. In 1954-1955, Parriat and Pesce rediscovered the site, as Méray did not publish anything about it (Parriat 1956). Since the 1950s, Daudey has been collecting annually at the site and reported about it briefly (Daudey, Bonnot 1970). So far only the Daudey collection can be assigned to one collector. Recently, these finds were the subject of a bachelor's thesis (Schiller 2018). Two test pit surveys are known. The first was conducted by Blaise in 1990 and remains unpublished (to our knowledge). Farizy conducted the second survey in 1994 (Farizy 1995a). There, 11 small test pits were made (each of 1 to $2 \mathrm{~m} 2$ ) evaluating a find layer on marl (around 60 to $80 \mathrm{~cm}$ under the field surface). Unfortunately, the archeological artifacts are affected by solifluction and the artifacts rarely lay flat on the ground. Desbrosse and Texier (1973a) report that they are aware of 10 prospectors of the site. In total, they were able to analyze $n=2,398$ pieces from the site (of these, $n=756$ were tools and $n=188$ were cores). A review of the finds from Musée Denon revealed $n=4,040$ lithic artifacts assigned to La Clôsure in total. According to the latest review in March 2019, a total of over 900 finds can be assigned to the Middle Paleolithic.

The assemblage of La Clôsure differs only slightly from the previous ones. Again, there is a great variety of bifacial objects in addition to the pieces with tranchet blow. So far, the $n=48$ bifacial objects include 30 bifaces and bifacially worked 
objects, including one Micoquian biface. Furthermore, there are $n=18$ Keilmesser, three of which show a tranchet blow modification, and $n=3$ blanks of tranchet blow. Here, too, the Levallois concept for blank production is dominant, accompanied by ventral reduction. Other reduction concepts are present to a lesser extent, but the use of the discoidal concept is evidenced by 11 cores, in contrast to 85 Levallois cores. The tools are dominated by side scrapers. Within this assemblage, the high occurrence of edge-blanks (éclats débordant and lame débordant) is significant.

The widely spaced test pits by Farizy suggested that a new survey campaign (scientific surveys with georadar, etc., coring, and selected test pits) could potentially provide further results and material for radiometric dating.

\subsection{Further sites}

The previously mentioned sites seem most important in terms of assemblage quantity. Nevertheless, there are further sites in their vicinity: The Grotte de la Mère Grand in Rully, for example, first excavated in the 1860s and then again in the 1950s (Combier 1959; Combier, Ayroles 1976; Herkert 2020) yielded a small but Levallois based industry with a fairly large amount of Levallois blades. Scrapers dominate the tool spectrum, but there are some small bifacial pieces as well.

The open-air site of En Roche in Germolles is known for its "Aurignacoid" Upper Paleolithic but also comprises a Middle Paleolithic component (Gros, Gros 2005; Guillard 1954; Herkert 2017; 2020; Herkert, Floss 2019; Herkert et al. 2016). Within the collections, the Levallois affinities are evident, and the tool spectrum is dominated by different types of scrapers. Despite a low number of quite unspecific bifacial elements, recently conducted surveys could identify first indications for the execution of tranchet blows on site. A small test-pit excavation in 2017 and 2018 confirmed the Middle Paleolithic presence in stratigraphical position (Herkert, Floss 2019). Gros and Gros (2005) indicate the presence of a non-specific Mousterian for En Roche and stress the presence of a Levallois component and Quina type scrapers.

Finally, there is the open-air site of Saint-Sulpice in Germolles. Situated on a flint outcrop, the site appears to have been a workshop. Tools are quite rare, but the numerous cores and blanks reveal a very high component of Levallois production with a particular focus on elongated blanks (Colbère 1979; Herkert 2020). While there certainly are other smaller assemblages in the Côte Chalonnaise area, for further considerations we would like to limit ourselves to those mentioned above.

\section{A comparative view}

Since the first use of the terms Mousterian (âge du Moustier, Mortillet 1869; Moustiérien, Mortillet 1873), Micoquian (Hauser 1915, 1916) or Middle Paleolithic (Mittelpaläolithikum, Rademacher 1911; middle paleolithic, Sollas 1911), it has been discussed whether different units can be separated within these. For Western Europe, scholars defined a vast variety of cultures, facies, technocomplexes, or time-space-units, based on the approach of the research object (index fossils, qualitative or quantitative typology, technological features, etc.). The allocations, which were initially quite subjective (presence of index fossils or types), have been replaced over time by more objective, verifiable classifications (presence of technological features characterized by strictly defined criteria).

Since the 1950s, a high degree of diversification was noticed (Bordes 1961; 1968; Bordes, Bourgon 1951; Bosinski 1967; Grahmann, Müller-Beck 1967; Müller-Beck 1956) especially for the recent phase of the Middle Paleolithic (today MIS 4 and 3). The ascriptions were modified over time by changing the criteria of locally separated and technologically more or less divergent entities (Fig. 2).

As Figure 3 reveals, the Côte Chalonnaise region in Eastern France is actually situated at a marginal position in relation to the extension of several late Middle Paleolithic complexes (e.g. Denticulés, Charentien à influence micoquienne, Mousterian with bifacial tools, Mousterian of Micoquian influence, Moustérien de tradition acheuléenne).

When we look at the different chronological attributions that have been assigned to the different assemblages in the Côte Chalonnaise in 150 years of regional research history, they have been attributed through typological assessments and different emphasis of different scholars to a large variety of different entities (Tab. 1). There are many varying correspondences between the neighboring entities, thus suggesting a very heterogeneous pattern for the region's occupation during the late Middle Paleolithic.

Throughout the history of research, the Middle Paleolithic at Grotte de la Verpillière I has been assigned to a multitude of different techno complexes, such as MTA (Campy et al. 1989; Combier 1959; Desbrosse et al. 1976; Gros, Gros 2005), Charentian Mousterian (Desbrosse, Texier 1973b), Charentien with Micoquian influence (Farizy 1995b), Micoquian (Uthmeier 2004), Mousterian with Micoque-Option (Richter 1997), Keilmessergruppen (Jöris 2003; hereafter: Keilmessergruppen) or Mousterian with bifacial tools (Ruebens 2012), mostly in reference to the presence of different forms of handaxes and other bifacial pieces.

For the material of La Roche, Pouliquen (1982; 1983) discussed an MTA affiliation because of the presence of some cordiform bifaces but prefers to see a local variety of the Rhodanian Quina Mousterian due to scrapers with bifacial retouch, convergent scrapers, and other scrapers showing a Quina type retouch. Combier (1962) and Gros (1964) went into a similar direction by defining a Quina type Mousterian and stressing the presence of Limaces, alongside the scrapers with Quine-like retouch.

Former research placed the material from Rue Cataux into an MTA context, because of the presence of cordiform handaxes (Combier 1959). For Guillard (1960), however, the predominance of typological Levallois elements made it to a Mousterian of Levallois facies. 


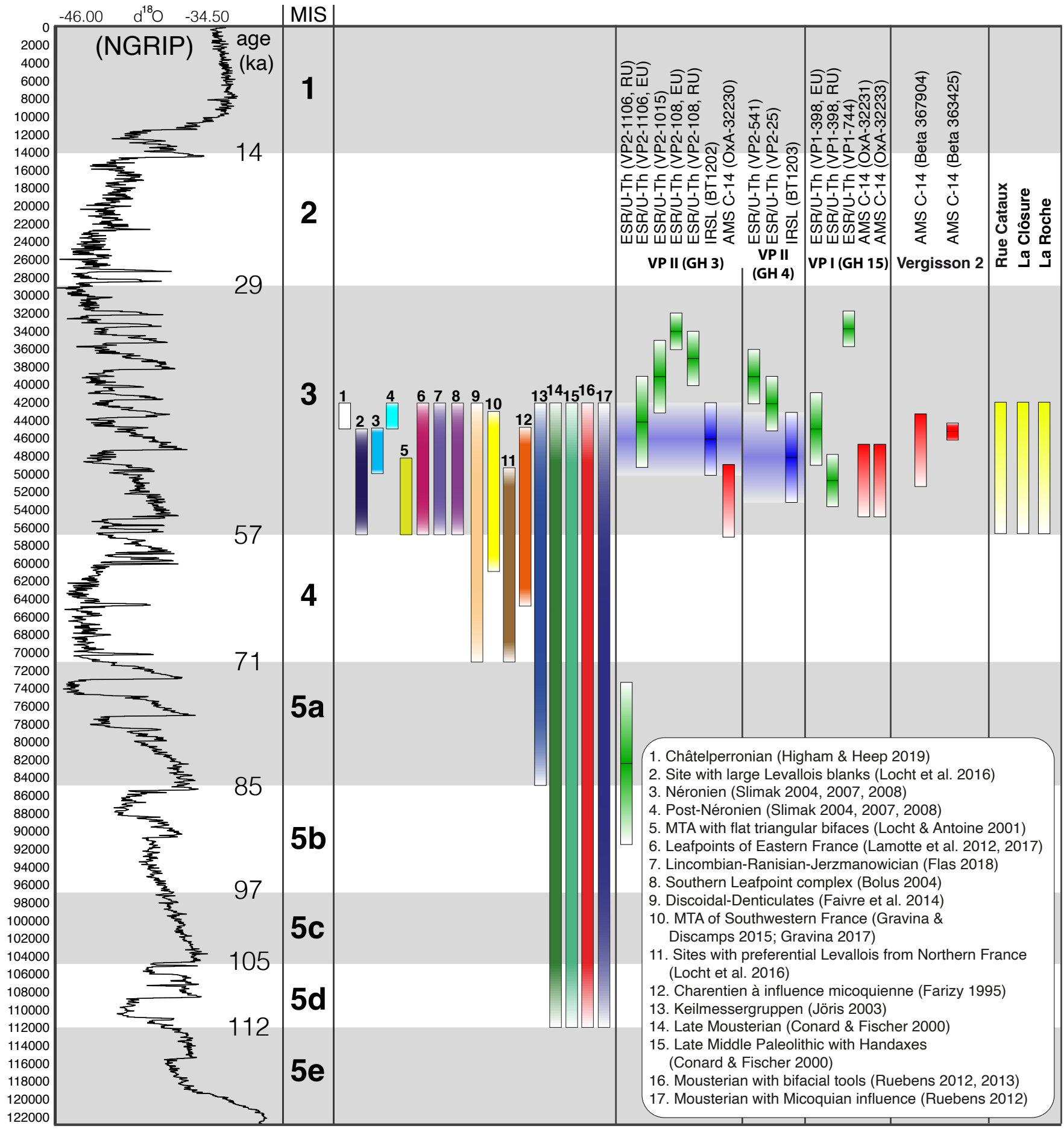

Figure 2. Chronological setting of late Middle Paleolithic entities and radiometric datings from Saône-et-Loire. The chronological setting of late Middle Paleolithic entities, based on Koehler (2009) and updated using the information provided by the following authors: Conard, Fischer 2000; Blaser, Chaussé 2016; Bolus 2004; Castel et al. 2017; Cliquet 2001; 2013; Faivre et al. 2014; Farizy 1995b; Flas 2018; Gouédo 1999; Gravina 2017; Gravina, Discamps 2015; Higham, Heep 2019; Jöris 2003; Koehler 2009; 2011; Lamotte et al. 2012; 2017; Locht, Antoine 2001; Locht et al. 2016; Ruebens 2012; 2013; Slimak 2004; 2007; 2008 and Soressi, Roussel 2014. For the radiometric data from Saône-et-Loire see: Frick 2016b; Heckel et al. 2016; Richard et al. 2016; Zöller, Schmidt 2016 and personal communication S. Quertelet and H. Floss. For Rue Cataux, La Clôsure and La Roche these are chronological assumptions. NGRIP record according to North Greenland Ice Core Project members (2004), Marine Isotope Stages according to Railsback et al. (2015). The chronological range relies on the literature cited above without strong stratigraphical correlation (especially for southwestern France, for example, the MTA (9) always predates the Chatelperronian (1), while there are sometimes other entities in between, see, e.g., Jaubert (2014)). (Composition: J. A. Frick)

At La Clôsure, Gros and Gros (2005) identified a simple Mousterian with bifaces. For Desbrosse and Texier (1973a) and Parriat (1956), the material showed affinities to a Charentien of Ferrassie type because of its predominance of
Levallois elements and a high occurrence of scrapers and different bifacial forms. The presence of bifaces within the assemblage led Farizy (1995a) to a Charentian with Micoquian influence attribution. 


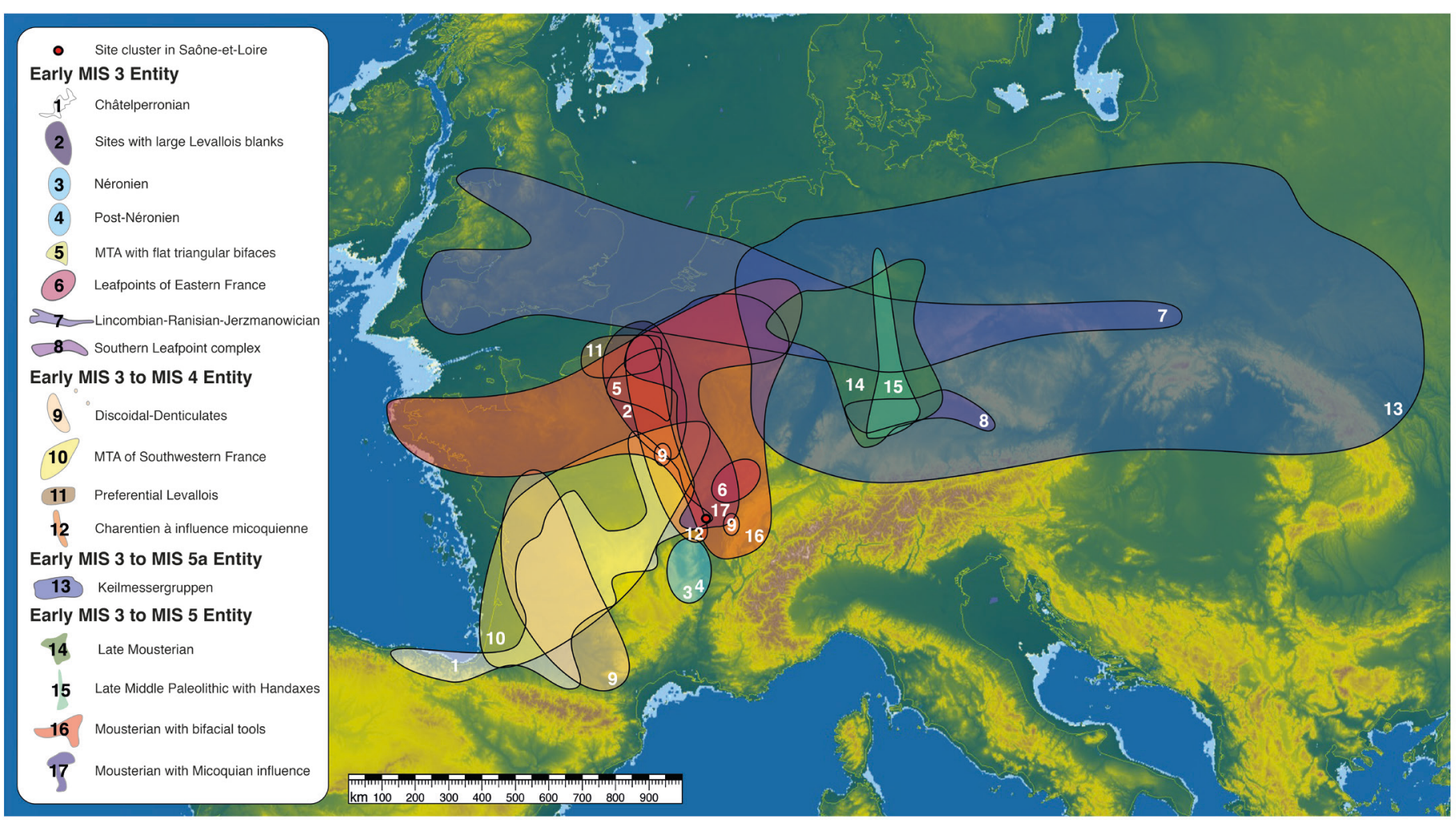

Figure 3. Spatial distribution of late Middle Paleolithic entities, based on Koehler (2009) and updated using the information provided by the following authors: Conard, Fischer 2000; Blaser, Chaussé 2016; Bolus 2004; Castel et al. 2017; Cliquet 2001; 2013; Faivre et al. 2014; Farizy 1995b; Flas 2018; Gouédo 1999; Gravina 2017; Gravina, Discamps 2015; Higham, Heep 2019; Jöris 2003; Koehler 2009; 2011; Lamotte et al. 2012; 2017; Locht, Antoine 2001; Locht et al. 2016; Ruebens 2012; 2013; Slimak 2004; 2007 ; 2008 and Soressi, Roussel 2014. The Côte Chalonnaise region is indicated (red dot), showing its marginal position within the different entities. The map is not exhaustive and only comprises entities defined for the early MIS 3 in central and western Europe. (Composition: J. A. Frick \& K. Herkert; base map: temporalmapping.org layer at GoogleEarthPro, available via https://web.archive.org/web/20130723034936/ http://www.temporalmapping.org/)

Based on sedimentological and typological issues (the presence of scrapers and bifaces and the absence of backed knives or Quina-type retouch), the assemblage of Mère Grand has previously been assigned to a final Micoquian (Combier 1959; Combier, Ayroles 1976). From a sedimentological point of view, Combier (1956-1957) compared the dominant find-layer with Vergisson II in the Mâconnais region, although he concluded a typical Quina industry there (Combier 2001).

For En Roche, the Middle Paleolithic component has been regarded as a simple Mousterian with Levallois elements. Additionally, the presence of Quina-like scrapers has been stressed (Gros, Gros 2005). Due to the observations from Saint-Sulpice, the predominance of the Levallois concept and the high occurrence of blades, Colbère (1979) classified the site as Mousterian of Levallois facies. The divergent chronological attributions for the Middle Paleolithic in the Côte Chalonnaise are summarized in Table 1.

In contrast to this and despite the contextual bias for some of the assemblages, our ongoing research was able to reveal several technological analogies between the assemblages, suggesting a much more homogeneous pattern than previously identified. Although the general quantitative composition of the five main sites already shows similarities (Fig. 4a \& 4b), especially between La Clôsure and Rue Cataux, and, to a certain extent, also La Roche, there are differences as well.
The differences concern the two cave sites, while the Verpillière II assemblage, deriving from modern excavation conditions, appears the most diverse. Nevertheless, based on characteristics identified by Frick (2016) in the analysis of the assemblages of Grotte de la Verpillière II, most of the following key features can also be observed within the other assemblages (Tab. 2):

- Presence of Keilmesser with and without tranchet blow

- Morphological diversity of bifacial objects

- Prevalent use of the Levallois reduction concept

- Almost no evidence of other elaborated reduction concepts

- Evidence of opportunistic reduction

- Ventral reduction on blanks used for the configuration of Levallois cores

- Incidental presence of blades

- Tools on blanks and cores

- Tools from cortical, configuration and target blanks

- Bulb reduction on tools

- Minor presence of Groszaki

- Minor presence of a dorsal reduction

- Minor presence of Janus flakes

- Hardly any „Upper Paleolithic“ tool types

- Evidence for hafting of tools 


\begin{tabular}{|c|c|c|c|}
\hline Site & Allocation & Criteria & Literature \\
\hline \multirow{9}{*}{$\begin{array}{l}\text { Grotte de la Verpillière I } \\
\text { - (Germolles) }\end{array}$} & Mousterian & presence of handaxes, points and scrapers & $\begin{array}{l}\text { Chabas 1872; Gros 1958; Méray } \\
\text { 1869, } 1876\end{array}$ \\
\hline & MTA & presence of specific bifaces (cordiform handaxes) & $\begin{array}{l}\text { Campy et al. 1989; Combier } \\
\text { 1959; Desbrosse et al. 1976; } \\
\text { Gros, Gros } 2005\end{array}$ \\
\hline & $\begin{array}{l}\text { Mousterian of Charentian } \\
\text { type }\end{array}$ & $\begin{array}{l}\text { presence of specific bifaces (pièce foliacée } \\
\text { biface)presence of side scrapers and specific cores } \\
\text { (discs and Levallois cores) }\end{array}$ & Desbrosse, Texier 1973 \\
\hline & $\begin{array}{l}\text { Charentian with Micoquian } \\
\text { influence }\end{array}$ & $\begin{array}{l}\text { presence of specific bifaces (Keilmesser), backed side } \\
\text { scrapers, side scrapers without bulb, bifacial side } \\
\text { scrapers, plano-convexe bifacial objects, etc. }\end{array}$ & Farizy 1995 \\
\hline & Micoquian & presence of specific bifaces (Keilmesser) & Uthmeier 2004 \\
\hline & Middle Paleolithic & & Slimak 2004 \\
\hline & KMG-B2 & $\begin{array}{l}\text { presence of specific bifaces (Keilmesser with tranchet } \\
\text { blow in Western Europe) }\end{array}$ & Jöris 2003 \\
\hline & $\begin{array}{l}\text { Mousterian with Micoque- } \\
\text { Option }\end{array}$ & $\begin{array}{l}\text { presence of specific bifaces (Ciemna knives with } \\
\text { tranchet blow) }\end{array}$ & Richter 1997 \\
\hline & Mousterian with bifacial tools & $\begin{array}{l}\text { presence of bifaces (classical and backed bifaces), } \\
\text { scrapers, points, notches and denticulates }\end{array}$ & Ruebens 2012 \\
\hline En Roche - (Germolles) & Mousterian & Levallois component, presence of Quina type scrapers & Gros, Gros 2005 \\
\hline $\begin{array}{l}\text { Saint Sulpice - } \\
\text { (Germolles) }\end{array}$ & Mousterian, Levallois Facies & predominance of the Levallois concept, many blades & Colbère 1979 \\
\hline \multirow{4}{*}{$\begin{array}{l}\text { La Roche - (Saint- } \\
\text { Martin-sous-Montaigu) }\end{array}$} & MTA (discussed) & some cordiform bifaces & Pouliquen 1982; 1983 \\
\hline & $\begin{array}{l}\text { Quina Rhodanian (local } \\
\text { variety) }\end{array}$ & $\begin{array}{l}\text { presence of scrapers with bifacial retouch, convergent } \\
\text { scrapers, Quina type retouch }\end{array}$ & Pouliquen 1982; 1983 \\
\hline & Mousterian Quina type & presence of Limaces and Quina type retouch & Combier 1962; Gros 1964 \\
\hline & $\begin{array}{l}\text { Charentian with Micoquian } \\
\text { influence }\end{array}$ & $\begin{array}{l}\text { presence of specific bifaces (Keilmesser), backed side } \\
\text { scrapers, side scrapers without bulb, bifacial side } \\
\text { scrapers, plano-convexe bifacial objects, etc. }\end{array}$ & Farizy 1995 \\
\hline $\begin{array}{l}\text { Grotte des Teux Blancs } \\
\text { - (Saint-Denis-de-Vaux) }\end{array}$ & $\begin{array}{l}\text { Upper Acheulian } \\
\text { (discussed)Mousterian } \\
\text { (rudimentary, archaic) }\end{array}$ & $\begin{array}{l}\text { large cordiform bifaceLevallois flakes and points, } \\
\text { scrapers, backed knives }\end{array}$ & Combier 1956 \\
\hline $\begin{array}{l}\text { Grotte de la Mère } \\
\text { Grand - (Rully) }\end{array}$ & Micoquian (final) & $\begin{array}{l}\text { sedimentology, typology (presence of bifaces and } \\
\text { scrapers), absence of backed knives or Quina type } \\
\text { retouch }\end{array}$ & $\begin{array}{l}\text { Combier 1959; Gros 1961; Gros, } \\
\text { Gros } 2005\end{array}$ \\
\hline \multirow{3}{*}{$\begin{array}{l}\text { La Clôsure - (Bissy-sur- } \\
\text { Fley) }\end{array}$} & Charentian of Ferrassie type & $\begin{array}{l}\text { predominance of Levallois concept, many scrapers, } \\
\text { different bifacial objects }\end{array}$ & $\begin{array}{l}\text { Desbrosse, Texier 1973; Parriat } \\
1956\end{array}$ \\
\hline & Mousterian & presence of bifaces, Levallois flakes and points & $\begin{array}{l}\text { Daudey, Bonnot (1970); Gros, } \\
\text { Gros } 2005\end{array}$ \\
\hline & $\begin{array}{l}\text { Charentian with Micoquian } \\
\text { influence }\end{array}$ & presence of specific bifaces (Keilmesser) & Farizy 1995 \\
\hline \multirow{2}{*}{$\begin{array}{l}\text { Rue Cataux - } \\
\text { (Chonôves) }\end{array}$} & MTA & presence of specific bifaces (cordiform handaxes) & Combier 1959 \\
\hline & Mousterian, Levallois Facies & predominance of Levallois concept & Guillard 1960 \\
\hline
\end{tabular}

Table 1. List of analyzed sites, highlighting the allocations given by different scholars according to their criteria used.

Accordingly, it seems worthwhile to examine these features in more detail, while the broad lines have already been sketched in a previous contribution (Herkert et al. 2020).

\subsection{Blank production and reduction}

In terms of blank production, for example, the Levallois concept is dominant (and in many cases the only elaborated blank production concept identified within the different assemblages). Where the archaeological context of the assemblages allows definite assignments, which appears difficult for surface collections, but can be demonstrated for the lithic industry from Verpillière II, there is also a high degree of opportunistic reduction. But in contrast to this, other specific reduction concepts, such as Quina or Discoid, only appear in very few examples, if they could have been identified at all.

Another common element related to the Levallois concept is the evidence of ventral cores on bigger flakes that show marginal (circumferential or semi-circumferential) Levalloislike configuration while profiting from the benefits of given convexities (like the bulb) for the anticipated production.

Furthermore, the analysis of the Levallois cores, in regards to the applied reduction mode (Boëda 1993; 1994; Boëda et al. 1990; Richter 1997), also demonstrates clear correspondences 


\begin{tabular}{|c|c|c|c|c|c|c|c|c|}
\hline & $\begin{array}{l}\text { Grotte de la } \\
\text { Verpillière } \\
\text { II } \\
\text { (Germolles) }\end{array}$ & $\begin{array}{l}\text { Grotte de la } \\
\text { Verpillière I } \\
\text { (Germolles) }\end{array}$ & $\begin{array}{l}\text { La Roche } \\
\text { (Saint - } \\
\text { Martinsous } \\
\text {-Montaigu) }\end{array}$ & $\begin{array}{l}\text { La Clôsure } \\
\text { (Bissy-sur- } \\
\text { Fley) }\end{array}$ & $\begin{array}{l}\text { La Rue } \\
\text { Cataux } \\
\text { (Chenôves) }\end{array}$ & $\begin{array}{c}\text { Saint- } \\
\text { Sulpice } \\
\text { (Germolles) }\end{array}$ & $\begin{array}{l}\text { En Roche } \\
\text { (Germolles) }\end{array}$ & $\begin{array}{l}\text { La Mère } \\
\text { Grand } \\
\text { (Rully) }\end{array}$ \\
\hline $\begin{array}{l}\text { Presence of Keilmesser (with and } \\
\text { without tranche! blow) }\end{array}$ & $x$ & $x$ & $x$ & $x$ & $x$ & - & - & - \\
\hline $\begin{array}{l}\text { Morphological diversity of } \\
\text { bifacial objects }\end{array}$ & $x$ & $x$ & $x$ & $x$ & $x$ & $x$ & $x$ & $x$ \\
\hline $\begin{array}{l}\text { Prevalent use of Levallois } \\
\text { reduction }\end{array}$ & $x$ & $x$ & $x$ & $x$ & $x$ & $x$ & $x$ & $x$ \\
\hline $\begin{array}{l}\text { Almost no evidence for other } \\
\text { reduction concepts }\end{array}$ & $x$ & $x$ & $x$ & $x$ & $x$ & $x$ & $x$ & $x$ \\
\hline $\begin{array}{l}\text { Evidence for opportunistic } \\
\text { reduction }\end{array}$ & $x$ & $x$ & $?$ & $?$ & $?$ & $x$ & $?$ & $?$ \\
\hline $\begin{array}{l}\text { Ventral reduction on blanks for } \\
\text { configuration of Levallois cores }\end{array}$ & $x$ & $x$ & $x$ & $x$ & - & $?$ & $x$ & - \\
\hline Incidental presence of blades & $x$ & $x$ & $x$ & $x$ & $x$ & $x$ & $x$ & $x$ \\
\hline Tools on blanks and cores & $x$ & $x$ & - & - & - & - & - & - \\
\hline $\begin{array}{l}\text { Tools from cortical, configuration } \\
\text { and target blanks }\end{array}$ & $x$ & $x$ & $x$ & $x$ & $x$ & $x$ & $x$ & $x$ \\
\hline Bulb reduction on tools & $x$ & $x$ & $\times$ & $x$ & - & $x$ & $x$ & $x$ \\
\hline Minor presence of Groszaki & $x$ & $x$ & - & $x$ & $x$ & - & - & $x$ \\
\hline $\begin{array}{l}\text { Minor presence of dorsal } \\
\text { reduction }\end{array}$ & $x$ & $x$ & $?$ & - & - & - & - & $?$ \\
\hline Minor presence of ventral flakes & $x$ & $x$ & $x$ & $x$ & - & - & - & - \\
\hline $\begin{array}{l}\text { Hardly any "Upper Paleolithic" } \\
\text { tool types }\end{array}$ & $x$ & $?$ & $?$ & $?$ & $?$ & $?$ & $?$ & $?$ \\
\hline Evidence for hafting of tools & $x$ & $x$ & $x$ & $x$ & $x$ & $?$ & $x$ & $x$ \\
\hline
\end{tabular}

Table 2. Cross table with the major assemblage characteristics according to Frick (2016b) (columns) and the different Middle Paleolithic assemblages (rows). Due to the decontextualized character of most of the assemblages, it is not always possible to determinate whether a criterion is fulfilled or not (e.g., presence of "Upper Paleolithic" tool types), but in most cases, a similar pattern is noticeable. Dark green: presence confirmed; Light green: present in small quantity; Dark red: absence confirmed; Light red: absence indicated after first overview; Yellow: (chronological) attribution unclear; Grey: no reliable data yet.

(Fig. 5). In total, several reduction modes are present, but the focus is clearly on a preferential or centripetal reduction, each comprising about one-third of the analyzed cores. In terms of size range when discarded, the Levallois cores form a very similar pattern, while only the two Verpillière sites provided fairly thick cores (Fig. 6).

In the same way, the blanks evince the prevalent use of Levallois reduction (Fig. 4a \& b). For the stratified material from Verpillière II, for example, unretouched Levallois blanks (i.e., flakes, blades, and points) comprise over $20 \%$ of the assemblage. A similar amount has been identified for La Roche. The sites of Rue Cataux or La Clôsure show values of $36 \%$ and even $39 \%$, respectively. The material from the ancient collections of Verpillière I contains the fewest amount of unretouched Levallois blanks, which could be related to the subjective bias of the ancient excavators.

The category of Levallois blanks contains Levallois flakes, Levallois blades, and Levallois points (according to Boëda's understanding, see also Frick, Herkert 2014). The quantitative composition of these three Levallois blank types shows that the spectrum is dominated by flakes, while blades and points differ slightly in their quantitative occurrence (Fig. 7).

\subsection{Bifacial Elements}

During their research history, bifacial elements have played an increasingly crucial role in the identification of Middle Paleolithic facies and thus its chronological attributions (e.g., Bordes 1961; 1984; Bosinski 1967; Valoch 1988). This is also noticeable for the Côte Chalonnaise assemblages (see Tab. 1). Despite the heterogeneous attributions, our recent research revealed strong similarities regarding the bifacial component. Concerning, for example, the Keilmesser as an emblematic bifacial tool, its presence at Verpillière I has long been considered as an isolated spot at the margins of the classical extension of the Central European Keilmessergruppen (e.g. Desbrosse et al. 1976; Jöris 2003). However, our recent investigation and re-examination of ancient collections from the 


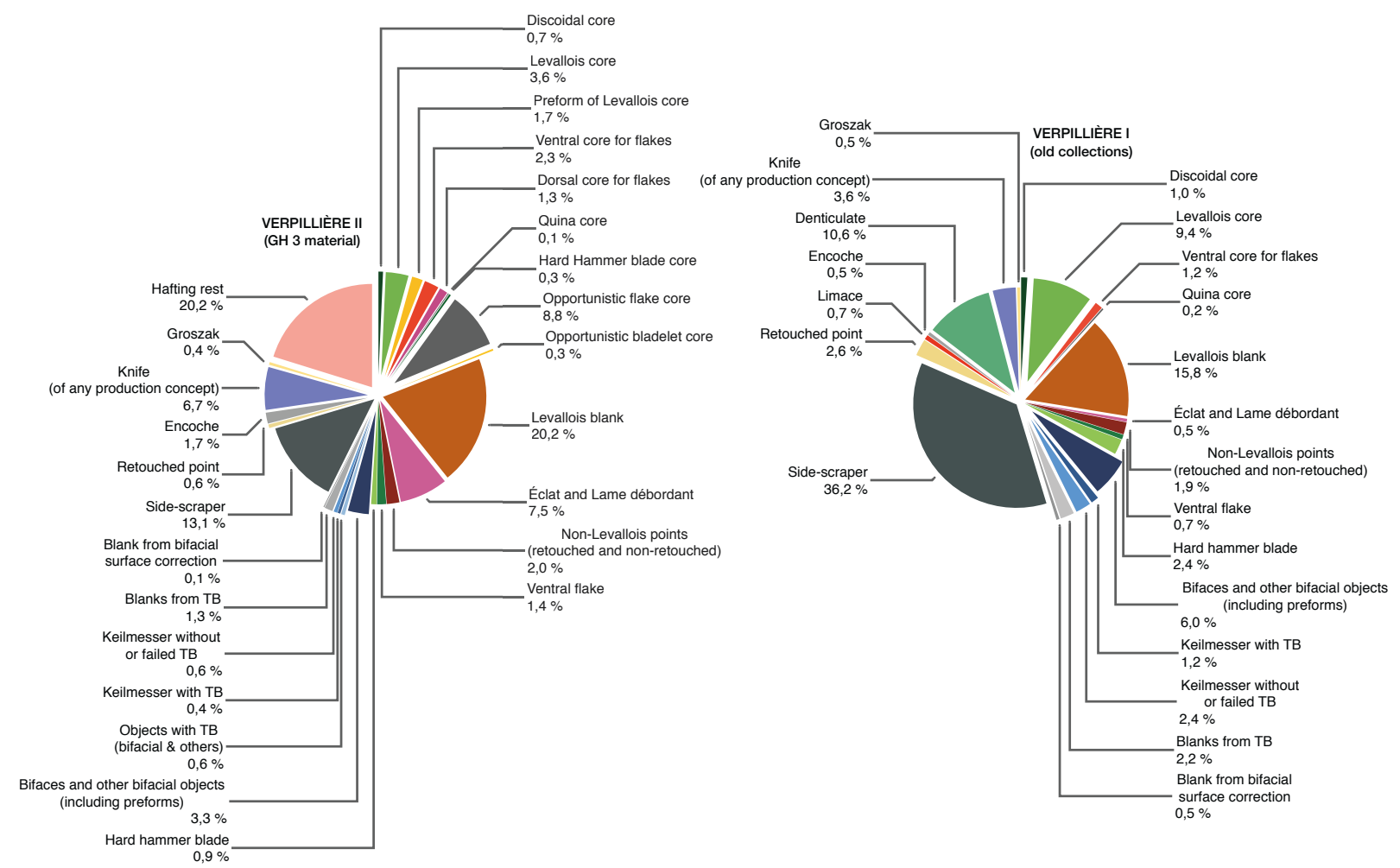

Figure 4a. Pie charts of the general assemblage composition of the two major Middle Paleolithic cave sites, the Grottes de la Verpillière I and II. The high diversification at Verpillière II is due to the modern excavation conditions.

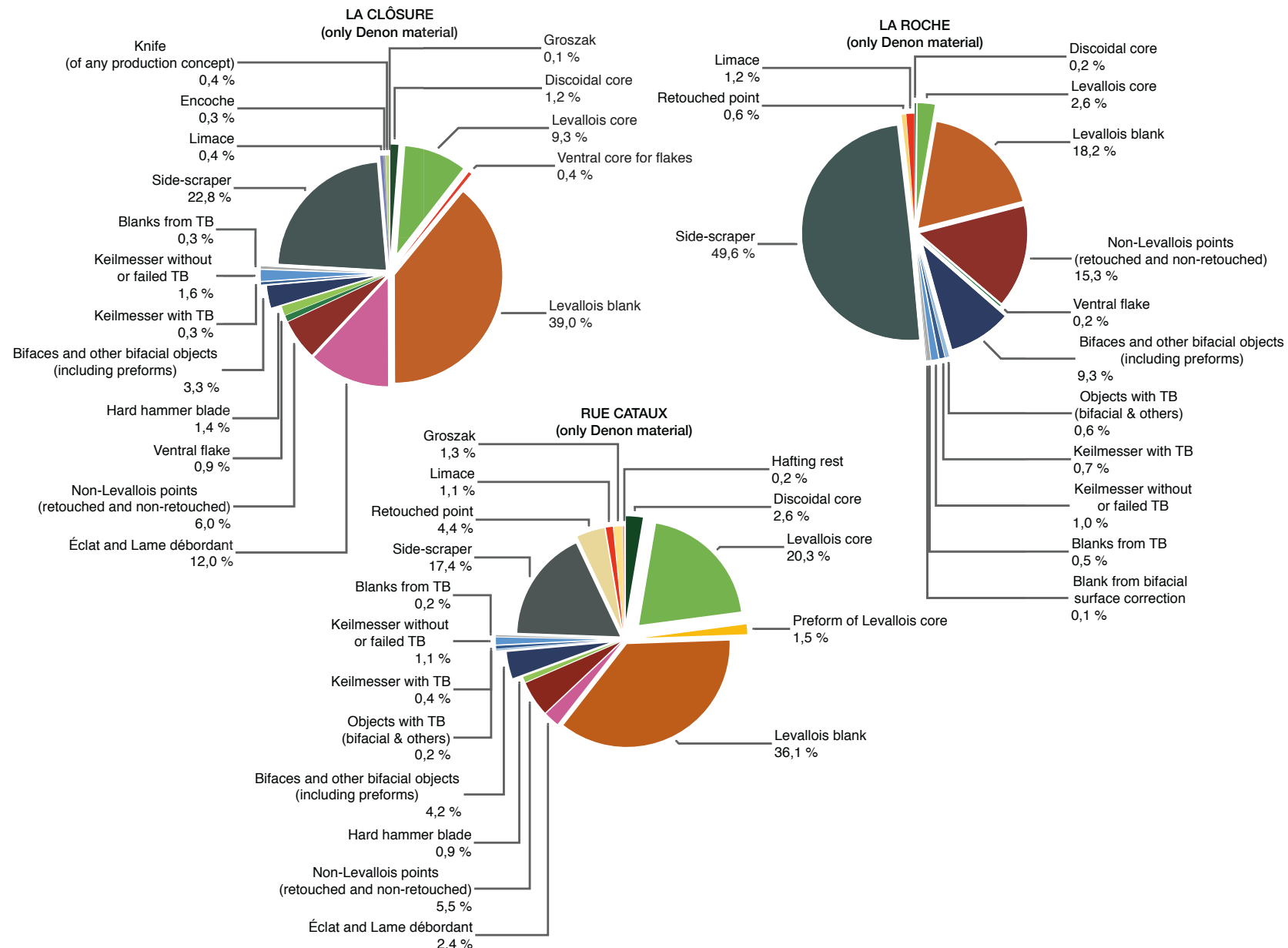

Figure 4b. Pie charts of the general assemblage composition of the three major Middle Paleolithic open air sites, La Roche, Rue Cataux and La Clôsure, where the similarities between the sites of Rue Cataux and La Clôsure and to a lesser extent of La Roche are worth noting. 


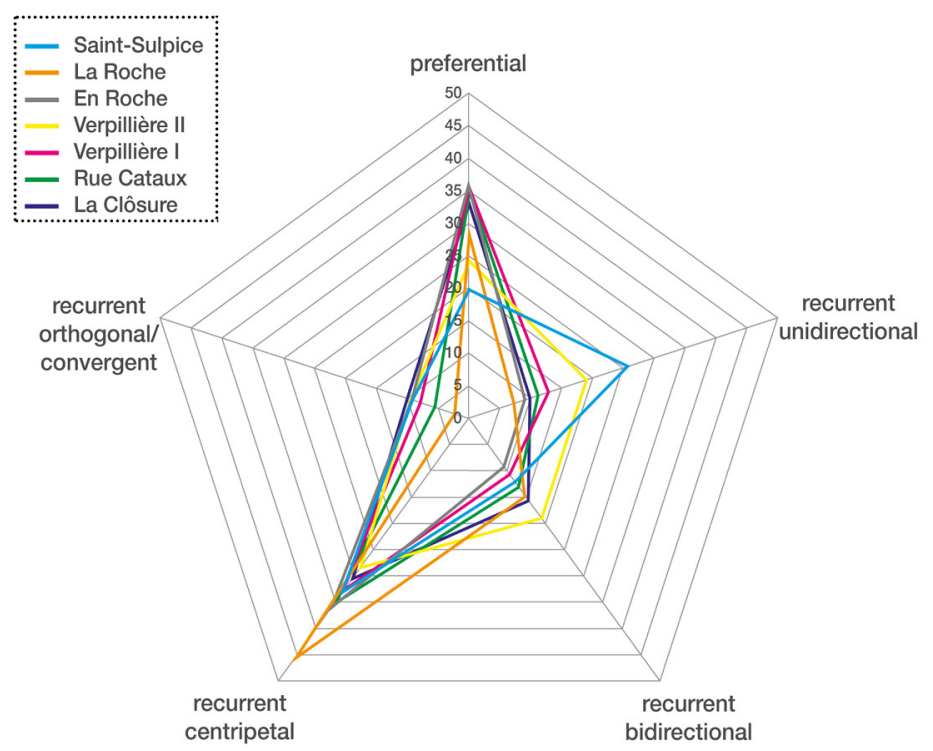

Figure 5. Net graph showing the percentage distribution of the different Levallois reduction modes observed at the analyzed sites. Total amount of analyzed cores: Saint-Sulpice $n=66$ (only Denon material), La Roche $n=41$ (Denon material and private collections from Donguy and Bonnotte), En Roche $n=11$ (Denon material and private collections from Donguy and Macioszczyk), Verpillière II $n=21$ (according to Frick (2016b)), Verpillière I $n=39$ (Denon material and private collection from Combier), Rue Cataux $n=54$ (only Denon material), La Clôsure $n=71$ (only Denon material).
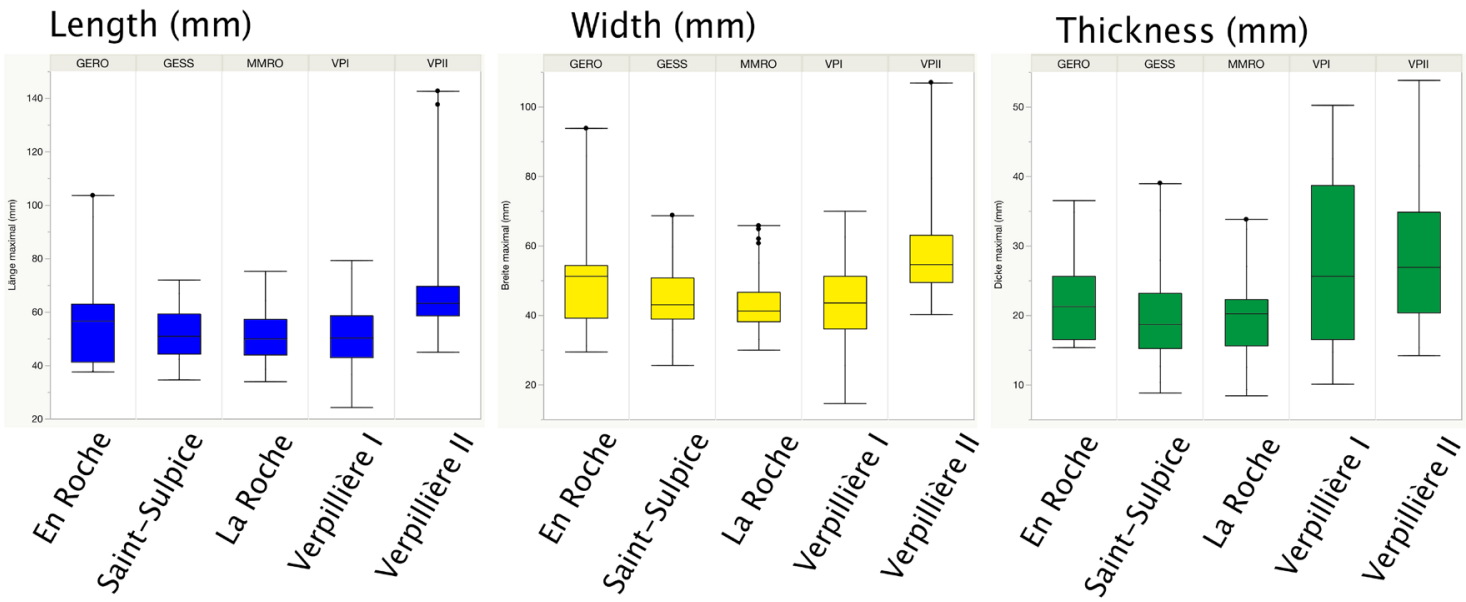

Figure 6. Comparative box plots of the maximum length, width and thickness of Levallois cores from different sites in the Côte Chalonnaise. Apart from the higher thickness values at the two cave sites, the size spectrum of the cores appears quite homogeneous.

Côte Chalonnaise could identify several additional sites containing Keilmesser, mostly even with a tranchet blow modification (Frick 2016b; Frick et al. 2020; Herkert et al. 2020; Herkert et al. 2015). The matrix for these pieces is highly variable and comprises either nodules, flakes, or frost shards. In addition to the mere existence of Keilmesser, it is above all the specific modification with a tranchet blow that must be emphasized and that links the different assemblages. On the one hand, the working stage analysis applied to the Keilmesser with tranchet blow from Grotte de la Verpillière I showed a high degree of variability and ramification, preceding the application of a tranchet blow. On the other hand, the results suggest a strong fidelity in the basal concept of the fabrication of these tools (Frick et al. 2017). For the neighboring sites, comparable analysis is in progress, but the morphological diversity already suggests a similar picture (Fig. 8).

Other bifacial elements that appear regularly within the assemblages are small Fäustel-type bifaces (Bosinski 1967). Like the Keilmesser, they are made from small nodules or flakes. Commonly, they have an asymmetrical, flat-convex crosssection, while the convex surface was shaped to a greater degree (Fig. 9). Overall, Fäustel have been observed at Verpillière I and II, at En Roche, La Roche, and at Mère Grand cave. 


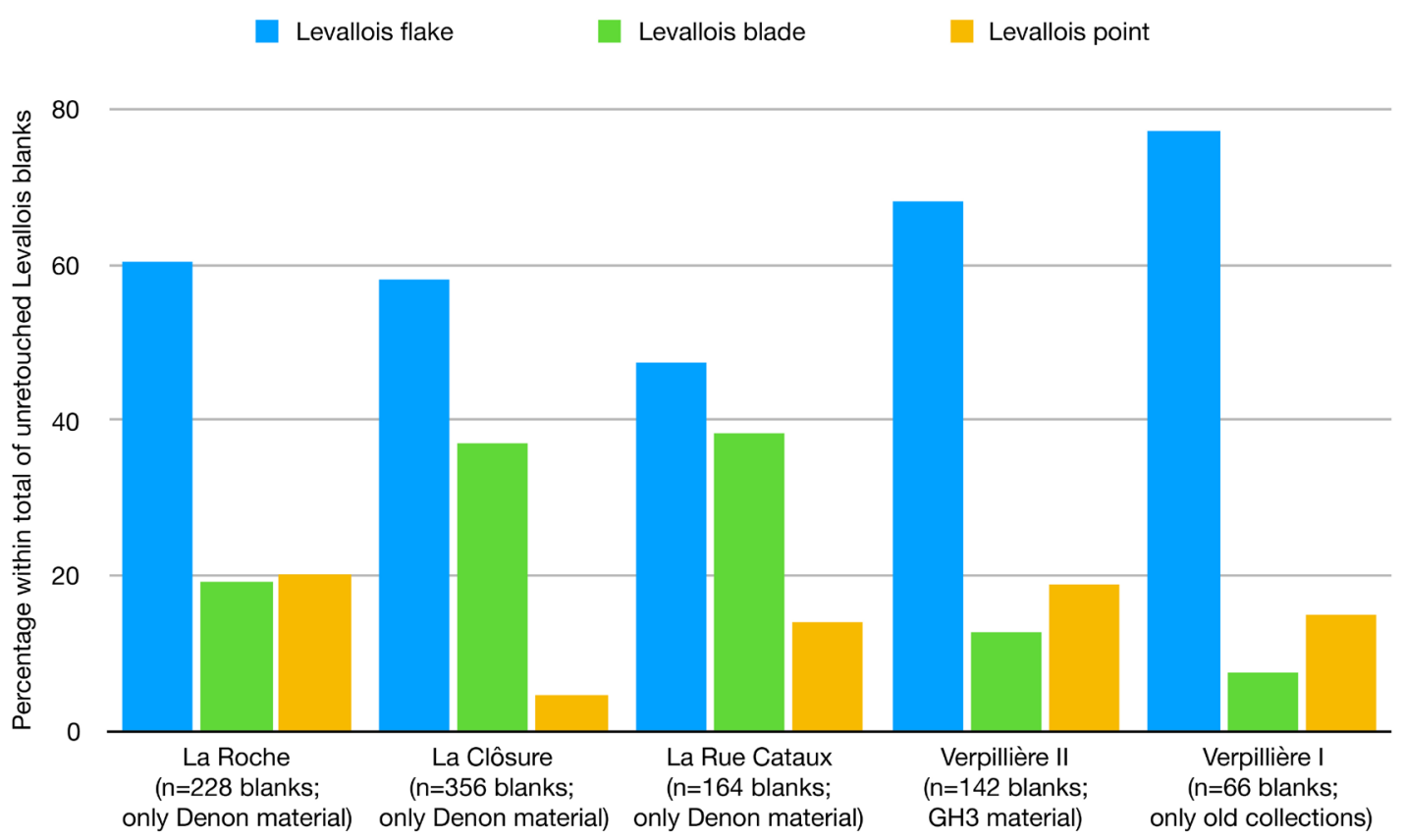

Figure 7. Bar graph showing the percentage distribution of unretouched Levallois blanks according to the blank-type.

In addition to these, other bifacially modified pieces are present in the assemblages. Among them, bifacial scrapers are quite common, which is especially true for La Roche, but also En Roche and Grotte de la Mère Grand.

Supplementing the bifacially worked elements, the assemblages also provide blanks that prove either on-site manufacturing or at least resharpening or reshaping activities, or the presence of specific blanks from tranchet blow evince the execution of tranchet blows. The latter is especially present in Verpillière I, and while some of these special finds already figure among the ancient collections, the majority derives from a recent excavation on the forecourt (Frick, Floss 2017; Frick et al. 2017). Figure 10 resumes the quantitative distribution of pieces related to bifacial tools or those that show evidence for the application of a tranchet blow. The high frequency of bifacial elements (in addition to Keilmesser) becomes evident. Furthermore, it is worth noting that the high number of blanks from tranchet blows, observable at Verpillière I and II, is mostly related to the recent excavation activities. Overall, the two cave sites provide a similar image, as do the open-air sites, respectively. Especially the presence of preforms becomes evident and could indicate their higher production rate at the cave sites and a higher discard rate of tools at the open-air sites.

\subsection{Tools and other characteristics}

It does not seem surprising that retouched tools are a very common feature within the assemblages. Therefore, the choice of blanks appears rather opportunistic, since blanks from different reduction stages (decortication, core configuration, core maintenance, blank production, target blanks, etc.) have been used for tool manufacture. This feature can be observed for all sites analyzed. Although tool quantity is high (but probably due to collection bias), the spectrum appears limited and is dominated by different forms of side-scrapers, which can compose up to half of the assemblages, as it is the case for the Musée Denon material of La Roche. The variety of side-scrapers comprises transversal, lateral, and bilateral edge modification.

Other common Middle Paleolithic tools such as Limaces (that have been used as descriptive elements, e. g., for La Roche), retouched points, notched pieces or denticulates only occur in small quantities. Only Verpillière I shows an elevated value of over $10 \%$ (with the highest number of denticulates), while the stratified material from Verpillière II comprises slightly more than $2 \%$, and the other sites are within a spectrum of between almost $1 \%$ and slightly over $5 \%$.

Concerning tool manufacture, bulb reduction is a further common characteristic that underlines the homogeneity of the assemblages. So far, it has been observed at six sites, while quantitative data is available only for La Roche, En Roche, and Verpillière II, where about $5 \%$ of the modified blanks evidence bulb reduction (Fig. 11).

This specific modification of ventral flattening is presumably linked to hafting purposes (Banks 2004; Rots 2010; 2016). Additionally, lateral notches or uni- or bilateral retouching can be observed on some of the tools as well as on tool fragments, indicating former hafting of tools, while the latter category (tool fragments) also suggests on-site retooling activities (Frick 2016b; Herkert et al. 2020).

\section{Discussion}

In the previous sections, we demonstrated the technologically coherent pattern of the Middle Paleolithic assemblages, which primarily relies on Levallois-focused blank production and various bifacial elements, whereby Keilmesser play a major role. 


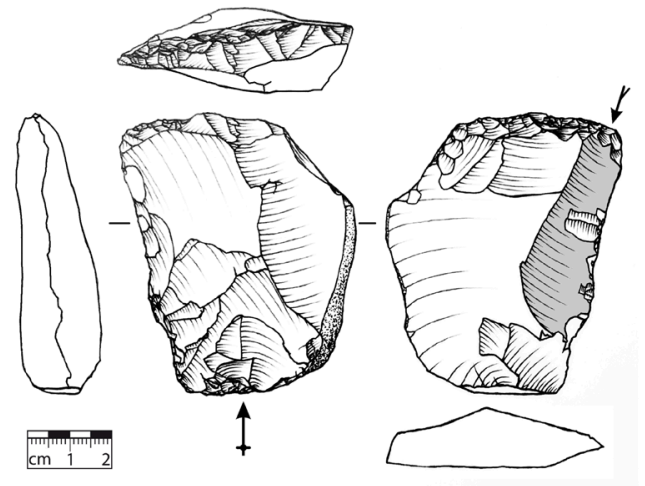

a) Denon 65.5 .1 box19 KM001

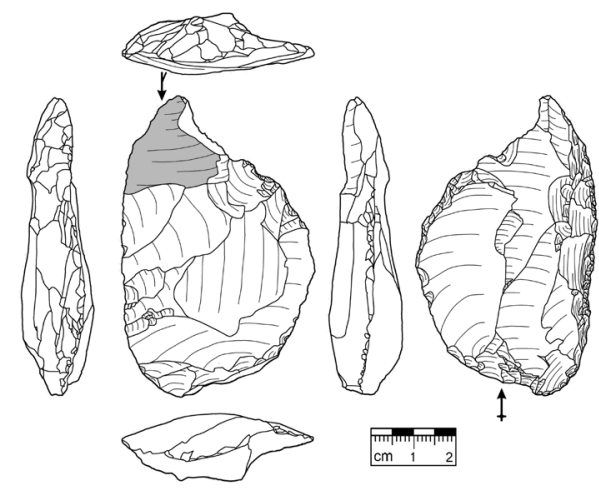

b)

Denon CA28.1101 box6
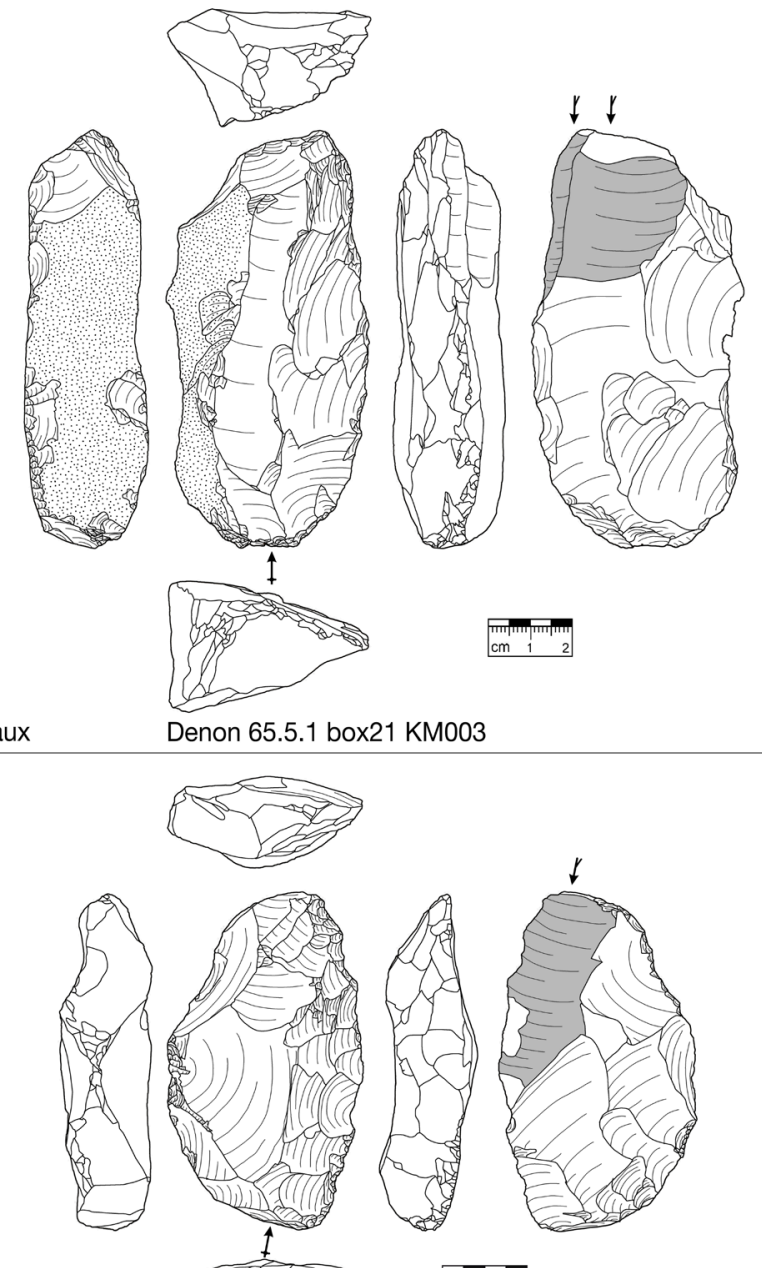

sets

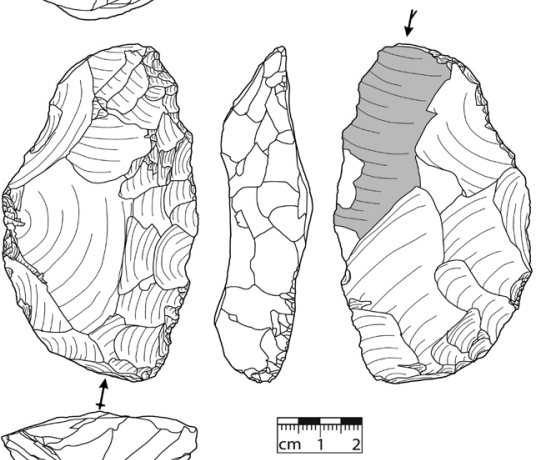

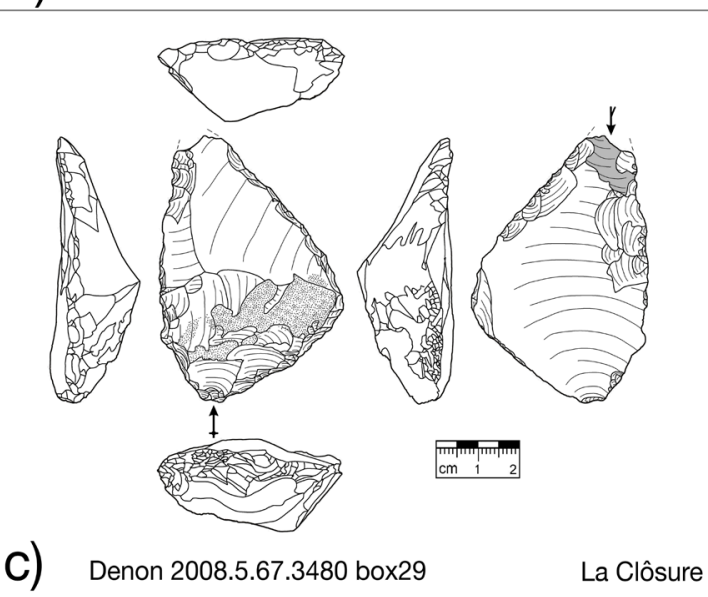

Denon CA28.830 box3

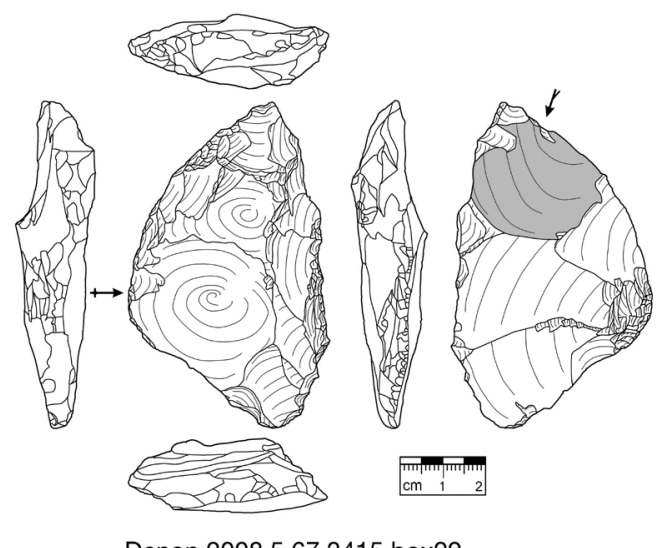

Figure 8. Keilmesser with tranchet blow (highlighted in gray) from a) Rue Cataux (Musée Denon Inv. No. 65.5 .1 box 19 KM001 \& 65.5.1 box 21 KM003); b) La Roche (Musée Denon Inv. No. CA28.1101 box 6 and CA28.830 box 3) and c) La Clôsure (Musée Denon Inv. No. 2008.5.67.3480 box 29 and 2008.5.67.3415 box 29). All pieces stored at Musée Denon in Chalon-our-Saône (drawings and composition: Frick, except 65.5.1.KM001 drawn by Rösch)

Detailed technological, morphometric, and metric analyses of the assemblages are in preparation and will contribute to the line of argument. A similar pattern shows the connection between various bifacial objects and the reduction utilizing the Levallois concept. Farizy (1995b) has already drawn attention to this connection. In her concept of the Charentien à influence micoquienne (Charentian with Micoquian influence, CIM), she highlighted the common occurrence of Levallois, bifaces, Fäustel, bifacial scrapers, and Pradniks, i.e. Keilmesser. 


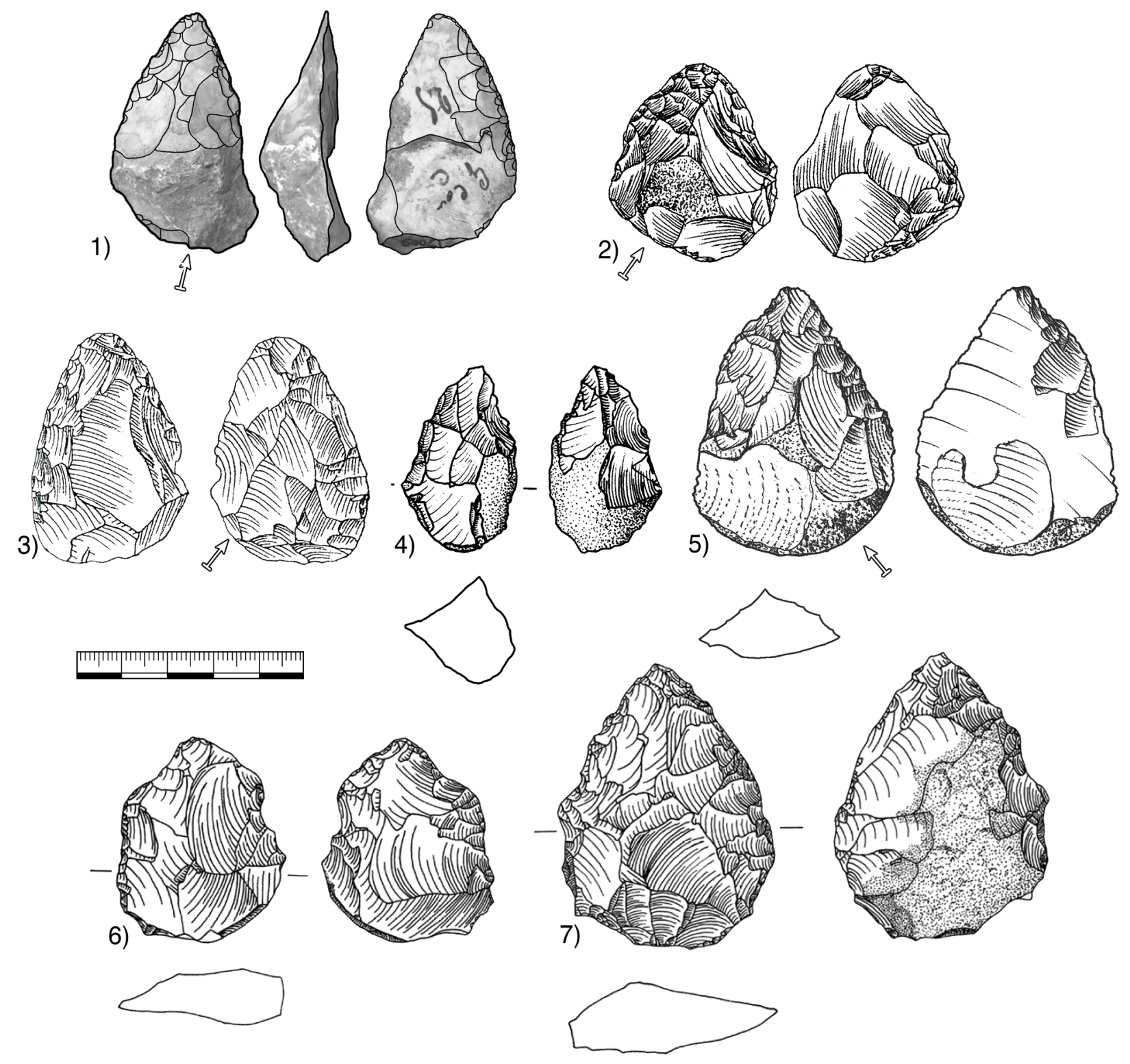

Figure 9. Small bifaces or Fäustel from different sites in the Côte Chalonnaise research area: 1) Grotte de la Mère Grand (MAN: Inv. No. 17.009; Drawing: Herkert); 2) En Roche (Denon: Inv.No. 02.23.345; Drawing: Gros 2005, p. 150 fig. 95.2); 3) La Roche (Denon: Inv. No. 02.7.1; Drawing: Gros 2005, p. 57 fig. 29.3); 4) Grotte de la Verpillière II (Inv.No. GER12.227-057.420, after Frick 2016, p. 461 fig. 269.a); 5) Grotte de la Verpillière II (Inv.No. GER13.227-057.1790 after Frick 2016, p. 461 fig. 269.b); 6) Grotte de la Verpillière I (Inv.No. GER07.197-110.18.1 after Floss (2008, p. 59 fig. 27.1)) 7) Grotte de la Verpillière I (Inv.No. GER07.195-094.52.1 after Floss 2008, p. 57 fig. 25.2).

In general, the co-occurrence of Keilmesser and other bifacial elements, especially Fäustel, has been stressed by other scholars (Bosinski 1967; Jöris 2003; Richter 1997; Veil et al. 1994) and underlines the chrono-technological coherence of the different assemblages.

Although it is not yet possible to chronologically fix the sites mentioned here, we would like to attempt listing chronological markers that already exist at this time (Fig. 2). In terms of absolute chronometric data, so far, the most reliable dates come from Grotte de la Verpillière II (via ESR/U-Th, IRSL, and AMS 14C), which point towards the early MIS 3. Dating of GH 15 material from Verpillière I (via ESR/U-Th and AMS 14C), which overlies the intact Middle Paleolithic in the cave, also points to the early MIS 3 (Heckel et al. 2016; Richard et al. 2016; Zöller, Schmidt 2016). In addition to the radiometric dating, the analysis of the micro-vertebrates by Jeannet (2014) provided evidence for a cool but humid climate setting during the deposition of the material forming GH 3 at Verpillière II. For the other sites in the Côte Chalonnaise, no chronometric data exists yet. Combier (1956-1957) correlated his sedimentological observations at Grotte de la Mère Grand at Rully with those of Vergisson II (Combier 2001), where recent 14C dating attempts on bone provided dates between 47 and 44 cal ka BP (BETA 367904 and BETA 363425; personal communication S. Quertelet and H. Floss).

In addition to these recent attempts to establish a chronological fixation based on radiometric data, other authors already attempted to at least include Verpillière I into their research. For example, Jöris (2002; 2003) included the site into his KMG B2, based on the presence of Keilmesser with 

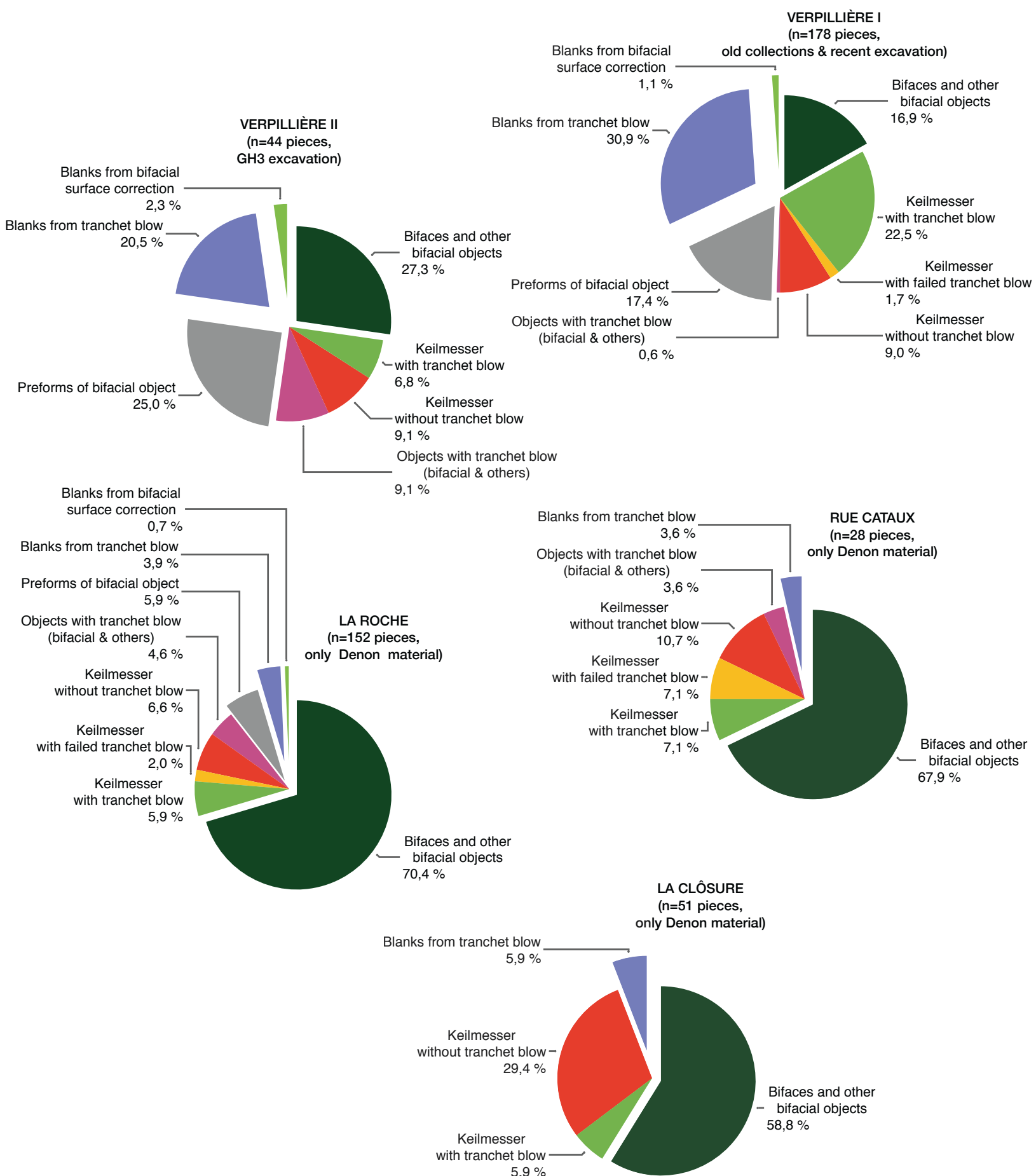

Figure 10. Pie charts showing the quantitative distribution of elements related to bifacial tools or the execution of tranchet blows.

tranchet blow and its spatial position in Western Europe. KMG B2 corresponds approximately to the second half of MIS 4 or the beginning of MIS 3. Nevertheless, further work on a firm chronological fixation for the presented site cluster is imperative.

As these attempts already demonstrate, it can be worthwhile to examine technological features. Rather than a mere fixation on discriminant morphotypes, analysis of the technological habitus, i.e. the identification of the techno-conceptual foundation, can help link assemblages. For the
Middle Paleolithic of the Côte Chalonnaise, such a technoconceptual basis is present, not only in the form of special reduction strategies but also in the manufacture of bifacial objects. Here, the focus is not on the morphological coherence of specific objects, such as Keilmesser, but on the final goal, the application of a tranchet blow, as could be demonstrated for Verpillière I (Frick et al. 2017; 2018). Thus, the sites are not explicitly linked via typology, but via a general lithoconceptual framework. Since no comprehensive working stage analysis has yet been carried out for pieces of the other sites, we can only present drawings of some of the Keilmesser 


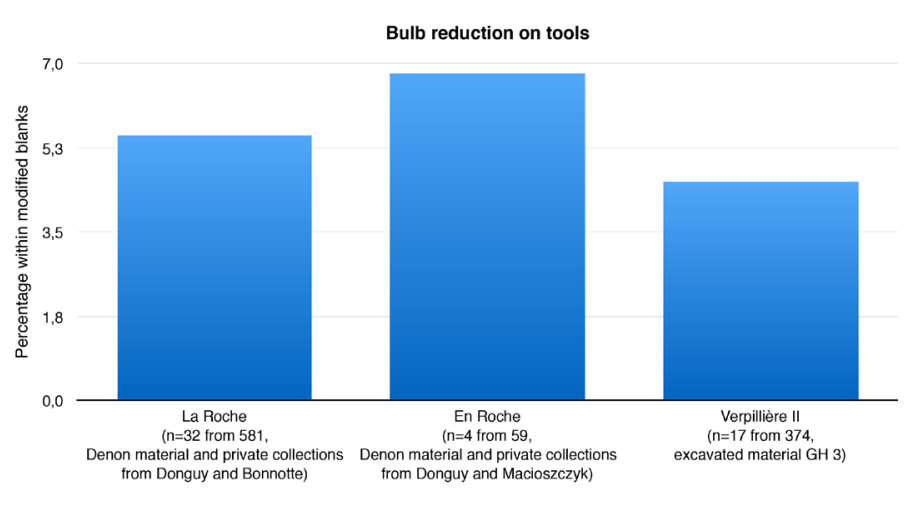

Figure 11. Bar graph showing the percentage of bulb reduction on modified blanks, i.e. tools, comprising the sites of La Roche, En Roche and Verpillière II.

with tranchet blow (Fig. 8). Nonetheless, as these simple illustrations already show, the pieces are quite different in terms of their morphology and their degree of shaping, although they evidence the tranchet blow application, something that Pouliquen (1982) did not recognize or mention in her work on the La Roche material.

If other known assemblages with evidence of tranchet blow are used as a basis, on a larger chronological scale, again, a striking accumulation is observed at the end of MIS 4 and the beginning of MIS 3 (Frick 2019). Verpillière I with its Keilmesser with tranchet blow assemblage has long been considered as an isolated spot of the Keilmessergruppen (Jöris 2003; Richter 1997). Our research was able to show that this phenomenon covers a whole region and is embedded in and linked to several other litho-technological characteristics, which could be interpreted as related to each other in a chrono-technological manner. So far, it is premature and not at all our intent to push the assemblages into an attribution to the Keilmessergruppen or the Charentien of Micoquian influence, into which they might seem to fit best. Thus far, our approach is to present the results in a more open context of considerations, that might better reflect the variability of late Neanderthal behavior and pave the way for new and fruitful discussion.

\section{Conclusion}

This paper is not an attempt to define a new techno-complex, nor do we try to force the different assemblages into one existing entity. Nevertheless, we find it worthwhile to reconsider the given traditional space-time units and their defining parameters. As the results show, there are several sites in the Côte Chalonnaise, whose assemblage composition comprises aspects which are or can be assigned to different geographically neighboring late Middle Paleolithic complexes, but which, as in the case of Verpillière II, form a coherent technological unit on their own. Therefore, the hypothesis of a technologically linked site cluster in the region seems appropriate to us. Therein, the major characteristics rely on homogeneous reduction strategies which are primarily based on Levallois, combined with the manufacture of morphological variable bifacial objects, which commonly evidence the presence of tranchet blow modifications, which, again, is a technically non-trivial feature. Further research and radiometric dating attempts could even strengthen this image and once again reveal the high flexibility and variability of late Neanderthal groups.

\section{Acknowledgments and statements}

This contribution is the result of the desire to compile the data collected over the years on the similarity of assemblages from the Côte Chalonnaise and to put them on a solid foundation. Our warmest thanks go to Dominique Rose, who, once again, polished our English. Furthermore, we are grateful to Harald Floss, Yves Pautrat, and the members of the SRA (Service Régional d'Archéologie), the staff of the Musée Denon as well as the local collectors Victor Donguy and Bernard Macioszczyk for our fruitful and amicable cooperation during the past few years. We would also like to thank the reviewers and editors of the journal who ensured that the manuscript was transformed into an article worth publishing.

Data availability statement. The authors confirm that the data supporting the findings of this study are available within the article. Further information is available from the authors upon request.

Disclosure statement. No potential conflict of interest was reported by the authors.

Funding statement. This work was supported by DFG (FR 4015/1-1) and DFG (SFB 1070 RessourcenKulturen).

\section{References}

Arcelin, A. (1872). Solutré ou les chasseurs de rennes de la France centrale. Histoire préhistorique. 1st. edn. Librairie de L. Hachette et C, Paris. Armand-Calliat, L. (1928). Procès-Verbaux. Séance du 30 avril 1927. Mémoires de la Société d'Histoire et d'Archéologie de Chalon-surSaône, 15, XXIII-XXVII.

Banks, W. E. (2004). Toolkit structure and site use: Results of a highpower use-wear analysis of lithic assemblages from Solutré (Saôneet-Loire), France. [Unpublished Doctoral Dissertation]. University of Kansas.

Blaser, F., \& Chaussé, C. (2016). Saint-Illiers-la-Ville and the Micoquian of Weichselian sequences of the Paris Basin. Quaternary International, 411/A, 163-178. https://doi.org/10.1016/j. quaint.2015.06.035

Boëda, É. (1993). Le débitage discoïde et le débitage Levallois récurrent centripède. Bulletin de la Société Préhistorique Française, 90(6), 392-404. https://doi.org/10.3406/bspf.1993.9669

Boëda, É. (1994). Le concept Levallois, variabilité des méthodes. Monographie du Centre de Recherches Archéologiques, Vol. 9. Éditions du CNRS, Paris.

Boëda, É., Geneste, J.-M., \& Meignen, L. (1990). Identification de chaînes opératoires lithiques du Paléolithique ancien et moyen. Paléo, 2, 43-80. https://doi.org/10.3406/pal.1990.988

Bolus, M. 2004. Settlement Analysis of Sites of the Blattspitzen Complex in Central Europe. In: N. J. Conard (Ed.), Settlement Dynamics 
of the Middle Paleolithic and Middle Stone Age (Vol. 2. pp. 201-226). Kerns Verlag.

Bordes, F. H. (1961). Typologie du Paléolithique ancien et moyen. Publications de l'Institut de préhistoire de l'Université de Bordeaux, Vol. 1. Delmas, Bordeaux.

Bordes, F. H. (1968). The Old Stone Age. World University Library, 1st. edn. McGraw-Hill Book Company, New York.

Bordes, F. H. (1984). Leçons sur le Paléolithique. Le Paléolithique en Europe, Vol. 2. Cahiers du Quaternaire, Vol. 7. Éditions du CNRS, Paris.

Bordes, F. H., \& Bourgon, M. (1951). Le complexe Moustérien: moustériens, levalloisien et tayacien. L'Anthropologie, 55(1-2), 1-23.

Bosinski, G. (1967). Die mittelpaläolithischen Funde im westlichen Mitteleuropa. Fundamenta A 4. Böhlau Verlag, Köln, Graz.

Campy, M., Chaline, J., \& Vuillemey, M. (1989). La Baume de Gigny (Jura). XXVIIe supplément à Gallia Préhistoire. Éditions du Centre National de la Recherche Scientifique, Paris.

Castel, J.-C., Discamps, E., Soulier, M.-C., Sandgathe, D., Dibble, H. L., McPherron, S. J. P., Goldberg, P., \& Turq, A. (2017). Neandertal subsistence strategies during the Quina Mousterian at Roc de Marsal (France). Quaternary International, 433, 140-156. https:// doi.org/10.1016/j.quaint.2015.12.033

Chabas, F. (1872). Études sur l'Antiquité historique d'après les sources égyptiennes et les monuments réputés préhistoriques. Imprimperie de J. Dejussieu und Maisonneuve et Companie, Chalon-sur-Saône and Paris.

Cliquet, D. (Ed.) (2001). Les industries à outils bifaciaux du Paléolithique moyen d'Europe occidentale. Actes de la table-ronde internationale organisée à Caen (Basse-Normandie - France) - 14 et 15 octobre 1999. Études et Recherches Archéologiques de l'Université de Liège, Vol. 98. Université de Liège, Liège, p. 237.

Cliquet, D. (2013). Les occupations paléolithiques en Normandie dans leur contexte chronostratigraphique : «bribes archéologiques ». Quaternaire, 24(3), 315-358. https://doi.org/10.4000/ quaternaire. 6755

Colbère, L.-G. (1979). Le Site Moustérien et Néolithique de GermollesSaint-Sulpice (Sâone-et-Loire). Revue Archéologique de l'Est et du Centre-Est, 30, 25-45.

Combier, J. (1956). La grotte des Teux-Blancs à Saint-Denis-des-Vaux (Saône-et-Loire). Acheuléen supérieur - Moustérien - Magdalénien. Mémoires de la Société d'Histoire et d'Archéologie de Chalonsur-Saône, 24(1), 46-56.

Combier, J. (1956-1957). Compte-Rendu des Fouilles 1956-1957. Résultats généraux. (Grotte de la Mère Grand à Rully). [Unpublished excavation report].

Combier, J. (1959). Circonscription de Lyon. Gallia préhistoire, 2, 109-133.

Combier, J. (1962). Circonscription de Lyon. Gallia préhistoire, 5(1), 229-306.

Combier, J. (2001). Le gisement paléolithique moyen de Vergisson II (France, Saône-et-Loire). Archeo-Inter-Publica, 1, 1-18.

Combier, J., \& Ayroles, P. (1976). Gisements Paléolithiques de Chalonnais. In Combier, J., \& Thevenot, J.-P. (Eds.), IX ième congrès de l' U.I.S.P.P. Livret-guide de l'excursion A8, Bassin du Rhone, Paléolithique et Néolithique (pp. 85-86). Éditions du Centre National de la Recherche Scientifique.

Conard, N. J., \& Fischer, B. (2000). Are there recognizable cultural entities in the german middle Palaeolithic? In A. Ronen, M. Weinstein-Evron (Eds.), Toward Modern Humans - The Yabrudian and the Micoquian 400-50 k-years ago - Proceedings of a Congress held at the University of Haïfa November 3-9, 1996. (British Archaeological Reports International Series, Vol. 850. pp. 7-21). Archaeopress.
Daudey, J., \& Bonnot, J.-J. (1970). La station moustérienne de Bissysur-Fley. Trouvailles récentes. La Physiophile, 73, 7-8.

Desbrosse, R., Kozlowski, J. K., \& Zuate y Zuber, J. (1976). Prodniks de France et d'Europe Centrale. L'Anthropologie, 80(3), 431-448.

Desbrosse, R., \& Texier, J.-P. (1973a). La Station Moustérienne de Bissy-sur-Fley (S.-et-L.). La Physiophile, 78, 8-31.

Desbrosse, R., \& Texier, J.-P. (1973b). Les silex de Germolles dans la collection Jeannin. La Physiophile, 79, 64-70.

Dutkiewicz, E. (2011). Die Grotte de La Verpillière I - 150 Jahre Forschungsgeschichte. Die Aufarbeitung und Auswertung der Altgrabungen des paläolithischen Fundplatzes Germolles (Commune de Mellecey, Saône-et-Loire, Frankreich). [Unpublished Magister's thesis], Eberhard Karls Universität Tübingen.

Dutkiewicz, E., \& Floss, H. (2015). La Grotte de la Verpillière I à Germolles, site de référence Paléolithique en Bourgogne méridional. Historique des 150 ans de recherche. La Physiophile, 162, 13-32.

Faivre, J.-P., Discamps, E., Gravina, B., Turq, A., Guadelli, J.-L., \& Lenoir, M. (2014). The contribution of lithic production systems to the interpretation of Mousterian industrial variability in southwestern France: The example of Combe-Grenal (Dordogne, France). Quaternary International, 350, 227-240. https://doi. org/10.1016/j.quaint.2014.05.048

Farizy, C. (1995a). Bissy-sur-Fley (Saône-et-Loire): site paléolithique moyen de La Clôsure, Sondages d'évaluation, campagne de 1994, Rapport de prospection thématique. S.R.A. Bourgogne.

Farizy, C. (1995b). Industries charentiennes à influences micoquiennes, l'exemple de l'Est de la France. Paléo, Supplément 1(1): 173178. https://doi.org/10.3406/pal.1995.1393

Flas, D. (2018). Northern Europe: Middle to Upper Paleolithic Transition. In C. Smith (Ed.), Encyclopedia of Global Archaeology (pp. 1-15). Springer International Publishing. https://doi. org/10.1007/978-3-319-51726-1_1854-2

Floss, H. (2007). Rapport de fouille programmée. Lieu-dit: Grotte de La Verpillière à Germolles Commune : Mellecey (71), Durée de l'opération : 17 - 30 septembre 2006. Abteilung für Ältere Urgeschichte und Quartärökologie, Tübingen.

Floss, H. (2008). Rapport de fouille programmée. Lieu-dit: Les Grottes de La Verpillière I et II à Germolles Commune : Mellecey (71); Durée de l'opération : 27 août - 21 septembre 2007. Abteilung für Ältere Urgeschichte und Quartärökologie, Tübingen.

Floss, H. (2009a). Rapport de fouille programmée. Lieu-dit: Les Grottes de La Verpillière I et II à Germolles Commune : Mellecey, Saône-et-Loire (71); Durée de l'opération : 25 août - 20 septembre 2008. Abteilung für Ältere Urgeschichte und Quartärökologie, Tübingen.

Floss, H. (2009b). Rapport de fouille programmée. Lieu-dit: Les Grottes de La Verpillière I et II à Germolles Commune : Mellecey, Saône-et-Loire (71); Durée de l'opération : 27 juillet - 18 septembre 2009. Abteilung für Ältere Urgeschichte und Quartärökologie, Tübingen.

Floss, H., Dutkiewicz, E., Frick, J., \& Hoyer, C. T. (2013a). Le Paléolithique supérieur ancien en Bourgogne du sud. In P. Bodu, Chehmana, L., Klaric, L., Mevel, L., Soriano, S., \& Teyssandier, N. (Eds.), Le Paléolithique supérieur ancien de l'Europe de Nord-Ouest. Réflexions et synthèses à partir d'un projet colectif de recherche sur le centre et le sud du Bassin parisien. Actes du colloque de Sens (15-18 avril 2009). Vol. Mémoire LVI de la Société préhistorique française (pp. 331-350). Société préhistorique française.

Floss, H., Heckel, C., Hoyer, C. T., \& Tartar, E. (2015). L’Aurignacien en Bourgogne méridionale. In White, R., Bourrillion, R. (Eds.): Aurignacian Genius. Art, Technology and Society of the First Modern Humans in Europe. P@lethnology, 2015(7), 167-190. https://doi. org/10.4000/palethnologie.793 
Floss, H., Hoyer, C. T., Frick, J. A., Heckel, C., \& Herkert, K. (2013b). La Grotte de la Verpillière II à Germolles, commune de Mellecey (Saône-et-Loire). Fouille programmée 2010-2012. Rapport annexe. Complément suite à la CIRA du février 2013. Abteilung für Ältere Urgeschichte und Quartärökologie, Tübingen.

Floss, H., Hoyer, C. T., Frick, J. A., Heckel, C., \& Herkert, K. (2013c). Rapport de fouille pluriannuelle 2010-2012. Rapport final et rapport 2012. Lieu-dit: Les Grottes de La Verpillière I et II à Germolles. Commune : Mellecey, Saône-et-Loire (71); Durée de l'opération : 29 juillet - 21 septembre 2012. Abteilung für Ältere Urgeschichte und Quartärökologie, Tübingen.

Floss, H., Hoyer, C. T., Frick, J. A., Herkert, K., \& Huber, N. (2016). Fouilles programmées pluriannuelles aux sites paléolithiques des Grottes de la Verpillière I \& II à Germolles, commune de Mellecey (Saône-et-Loire). Rapport annuel 2015 - Rapport pluriannuel 2013 à 2015. Abteilung für Ältere Urgeschichte und Quartärökologie, Tübingen.

Floss, H., Hoyer, C. T., \& Würschem, H. (2017). Le Châtelperronien de Germolles (Grotte de La Verpillière I, commune de Mellecey, Saône-et-Loire, France). Paléo, 27, 149-176. https://doi. org/10.4000/paleo.3208

Frick, J. A. (2010). Les Outils du Néandertal. Technologische und typologische Aspekte mittelpaläolithischer Steinartefakte, am Beispiel der Grotte de la Verpillière I bei Germolles, Commune Mellecey, Saôneet-Loire (71), Frankreich. [Unpublished Magister's thesis]. Eberhard Karls Universität Tübingen.

Frick, J. A. (2016a). A Late Middle Palaeolithic assemblage containing Levallois and bifacial objects from Saône-et-Loire, France: GH 3 at Grotte de la Verpillière II à Germolles. Journal of Lithic Studies, 3(2), 1-36. https://doi.org/10.2218/jls.v3i2.1408

Frick, J. A. (2016b). On technological and spatial patterns of lithic objects. Evidence from the Middle Paleolithic at Grotte de la Verpillière II, Germolles, France. Doctoral Dissertation. Eberhard Karls Universität Tübingen. http://dx.doi.org/10.15496/publikation-14816

Frick, J. A. (2019). The spatial and temporal distribution of the tranchet blow phenomenon during the Middle Paleolithic in Western and Central Europe. In Maier, A. (Ed.) 61st Annual Meeting of the Hugo Obermaier Society in Erkrath (pp. 23-24). Verlag Dr. Faustus.

Frick, J. A., \& Floss, H. (2017). Analysis of bifacial elements from Grotte de la Verpillière I and II (Germolles, France). Quaternary International, 428, Part A, 3-25. https://doi.org/10.1016/j. quaint.2015.10.090

Frick, J. A., \& Herkert, K. (2014). Lithic technology and logic of technicity. Mitteilungen der Gesellschaft für Urgeschichte, 23, 129-172.

Frick, J. A., Herkert, K., Hoyer, C. T., \& Floss, H. (2017). The performance of tranchet blows at the Late Middle Paleolithic site of Grotte de la Verpillière I (Saône-et-Loire, France). PLoS ONE, 12(11), Article e0188990. https://doi.org/10.1371/journal.pone.0188990

Frick, J. A., Herkert, K., Hoyer, C. T., \& Floss, H. (2018). Keilmesser with tranchet blow from Grotte de la Verpillière I (Germolles, Saôneet-Loire, France). In P. Valde-Nowak, Sobczyk, K., Nowak, M., \& Źrałka, J. (Eds.), Multas per Gentes et Multa per Saecula. Amici Magistro et Collegae suo loanni Christopho Kozłowski dedicant (pp. 2536). Alter Publishing House.

Frick, J. A., Herkert, K., Hoyer, C. T., \& Floss, H. (2020). Using the technological feature of tranchet-blow performance on Keilmesser as connecting element for similar Middle Paleolithic assemblages from the Côte chalonnaise (Saône- et-Loire, France). In Conference Proceedings: The Rhine during the Middle Paleolithic: Boundary or Corridor? Sélestat, May 15th and 16th 2017. [Manuscript submitted for publication]
Gouédo, J.-M. (1999). Le technocomplexe micoquien en Europe de l'ouest et centrale: exemples de trois gisements du sud-est du basin parisien, Vinneuf et Champlost (Yonne), Verrières-le-Buisson (Essonne). [Unpublished Doctoral thesis]. Université des Sciences et Technologies de Lille 1 .

Grahmann, R., \& Müller-Beck, H. (1967). Urgeschichte der Menschheit (3rd edn). W. Kohlhammer Verlag.

Gravina, B. (2017). Intra-level technological change and its implications for Mousterian assemblage variability. The example of Le Moustier, layer G. Quaternary International, 433/B, 132-139. https://doi.org/10.1016/j.quaint.2016.02.061

Gravina, B., \& Discamps, E. (2015). MTA-B or not to be? Recycled bifaces and shifting hunting strategies at Le Moustier and their implication for the late Middle Palaeolithic in southwestern France. Journal of Human Evolution, 84, 83-98. https://doi.org/10.1016/j. jhevol.2015.04.005

Gros, A.-C. (1958). La Grotte de la Verpillière à Germolles (Saône-etLoire). L'Eduen - Bulletin Trimestriel de la Société d'Histoire Naturelle d'Autun, 8, 7-8.

Gros, A.-C. (1961). Compte rendu des journées "Préhistoire" de la S.E.R.S.A 1961. L'Eduen - Bulletin trimestriel de la Société d'Histoire Naturelle d'Autun, 20, 3-7.

Gros, A.-C. (1964). La Vallée des Vaux et les stations préhistoriques de St-Martin-sous-Montaigu (S.-et-L.). L' Eduen - Bulletin trimestriel de la Société d'Histoire Naturelle d'Autun, 6, 9-13.

Gros, O., Gros, A.-C. (2005). Le Chalonnais Préhistorique. Collections du Musée de Chalon-sur-Saône. Somapub Impressions.

Guillard, E. (1947). La station paléolithique de la „Roche” à SaintMartin-sous-Montaigu. Mémoires de la Société d'Histoire et d'Archéologique de Chalon-sur-Saône, 32(1), 48-60.

Guillard, E. (1954). Une Station Aurignacienne Inédite à Germolles. Mémoires de la Société d'Histoire et d'Archéologie de Chalon-surSaône, 33(2), 129-138.

Guillard, E. (1960). Note sur les Stations et Vestiges Préhistoriques de la Côte Chalonnaise trouvés à Chenoves, Saules et à I'Est de Culles-les-Roches. Le Gisement Préhistorique de la Rue Cataux (Chenôves). La Physiophile, 52, 5-16.

Hauser, O. (1915). Letter of Otto Hauser to Berliner Gesellschaft für Anthropologie, Ethnologie und Urgeschichte. Zeitschrift für Ethnologie, 47, 443-444.

Hauser, O. (1916). La Micoque, die Kultur einer neuen Diluvialrasse. Veit und Companie.

Heckel, C., Higham, T., Floss, H., \& Hoyer, C. T. (2016). Radiocarbon dating of Verpillière I and II. In H. Floss, Hoyer, C. T., Frick, J. A., \& Herkert, K. (Eds.), Projet Collectif de Recherche - Le Paléolithique supérieur ancien en Bourgogne méridionale. Genèse, chronologie et structuration interne, évolution culturelle et technologique. Rapport annuel 2015 (pp. 30-37). Abteilung für Ältere Urgeschichte und Quartärökologie, Tübingen \& S.R.A. Dijon.

Herkert, K. (2014). Prospections archéologiques en Côte Chalonnaise. In H. Floss, Hoyer, C. T., Frick, J. A., \& Herkert, K. (Eds.), Projet Collectif de Recherche - Le Paléolithique supérieur ancien en Bourgogne méridionale. Genèse, chronologie et structuration interne, évolution culturelle et technologique. Rapport annuel 2014 (pp. 255-277). Abteilung für Ältere Urgeschichte und Quartärökologie, Tübingen \& S.R.A. Dijon.

Herkert, K. (2017). L'industrie lithique de Germolles en Roche. In H. Floss, Hoyer, C. T., Frick, J. A., \& Herkert, K. (Eds.), Projet Collectif de Recherche - Le Paléolithique supérieur ancien en Bourgogne méridionale. Genèse, chronologie et structuration interne, évolution culturelle et technologique. Rapport annuel 2016 (pp. 47-60). Abteilung 
für Ältere Urgeschichte und Quartärökologie, Tübingen \& S.R.A. Dijon.

Herkert, K. (2020). Das späte Mittel- und frühe Jungpaläolithikum der Côte Chalonnaise. Betrachtungen zu lithotechnologischen Verhaltensweisen nebst forschungsgeschichtlicher Erörterungen - Eine Bestandsaufnahme - [unpublished Doctoral Dissertation] Eberhard Karls Universität Tübingen.

Herkert, K., \& Floss, H. (2019). Rapport de fouille programmée. Germolles „En Roche“, commune de Mellecey (Saône-et-Loire, BourgogneFranche-Comté). Durée de l'intervention du 30 juillet au 21 septembre 2018. Abteilung für Ältere Urgeschichte und Quartärökologie, Tübingen \& S.R.A. Dijon.

Herkert, K., Litzenberg, R., Hoyer, C. T., Frick, J. A., \& Floss, H. (2020). The Middle Paleolithic of the Côte Chalonnaise. Chronology, Technology and Palethnological elements. In Conference Proceedings: The Rhine during the Middle Paleolithic: Boundary or Corridor? Sélestat, May 15th and 16th 2017. [Manuscript submitted for publication]

Herkert, K., Macioszczyk, B., \& Floss, H. (2016). Prospections à Germolles en Roche. In H. Floss, Hoyer, C. T., Frick, J. A., \& Herkert, K. (Eds.), Projet Collectif de Recherche - Le Paléolithique supérieur ancien en Bourgogne méridionale. Genèse, chronologie et structuration interne, évolution culturelle et technologique. Rapport annuel 2015 (pp. 98-105). Abteilung für Ältere Urgeschichte und Quartärökologie, Tübingen \& S.R.A. Dijon.

Herkert, K., Siegeris, M., Chang, J.-Y., Conard, N. J., \& Floss, H. (2015). Zur Ressourcennutzung später Neandertaler und früher moderner Menschen. Fallbeispiele aus dem südlichen Burgund und der Schwäbischen Alb. Mitteilungen der Gesellschaft für Urgeschichte, 24, 141-172.

Higham, T. F. G., \& Heep, G. S. (2019). Reply to: 'In the eye of the beholder: contextual issues for Bayesian modelling at the Middle-to-Upper Palaeolithic transition', by Discamps, Gravina and Teyssandier (2015). World Archaeology, 51(1), 126-133. https://doi.or g/10.1080/00438243.2017.1329026

Jacquin, A. (1896). Excursions de Château-Beau et de Montaigu, le 26 avril 1896. Bulletin de la Société des Sciences Naturelles de Saône-etLoire, 5, 95-102.

Jaubert, J. (2014). Middle Palaeolithic Archeo-Sequences from Southwestern France: Where do we stand a quarter century after François Bordes? In Derevianko, A. P., \& Drozdov, N. I. (Eds.), Topical Issues of the Asian Paleolithic. Proceedings of the International Symposium in Krasnoyarsk, July 6-12, 2012 (pp. 44-62). Institute of Archaeology and Ethnography Press.

Jeannet, M. (2014). Germolles II, les microvertébrés du niveau 3, Taphonomie et environnement. In H. Floss, Hoyer, C. T., Frick, J. A., \& Herkert, K. (Eds.), Projet Collectif de Recherche - Le Paléolithique supérieur ancien en Bourgogne méridionale. Genèse, chronologie et structuration interne, évolution culturelle et technologique. Rapport annuel 2014 (pp. 200-213). Abteilung für Ältere Urgeschichte und Quartärökologie, Tübingen.

Jöris, O. (2002). Die aus der Kälte kamen... von der Kultur Später Neandertaler in Mitteleuropa. Mitteilungen der Gesellschaft für Urgeschichte, 11, 5-32.

Jöris, O. (2003). Zur chronostratigraphischen Stellung der spätmittelpaläolithischen Keilmessergruppen. Der Versuch einer kulturgeographischen Abgrenzung einer mittelpaläolithischen Formengruppe in ihrem europäischen Kontext. Bericht der Römisch-Germanischen Kommission, 84, 49-153.

Koehler, H. (2009). Comportements et identité techniques au Paléolithique moyen dans le Bassin parisien : une question d'échelle d'analyse?
[Unpublished Doctoral Dissertation]. Université de Paris OuestNanterre La Défence.

Koehler, H. (2011). Comportements et identité techniques au Paléolithique moyen dans le Bassin parisien: une question d'échelle d'analyse? Presses universitaires de Paris Ouest. https://doi.org/10.4000/ books.pupo.3905

Lamotte, A., Aubry, D., Debenham, N., Magniez, P., Le Mené, F., \& Galtier, F. (2012). Le gisement paléolithique de Pont-de-Planches (Haute-Saône, France): cadre paléoenvironnemental et datations des occupations du Paléolithique moyen et Paléolithique supérieur. Quaternaire, 23(4), 291-308. https://doi.org/10.4000/ quaternaire.6373

Lamotte, A., Chanson, J.-M., Willemann, G., \& Galtier, F. (2017). Handaxes and leafpoints of eastern France: Spatial patterns and role of the raw materials. Quaternary International, 428/A, 79-90. https://doi.org/10.1016/j.quaint.2015.10.110

Lènez, L.-A. (1926). Une nouvelle station du Paléolithique supérieur dans l'arrondissement de Chalon-sur-Saône. L'Homme Préhistorique 13(11): 231-245.

Litzenberg, R. (2015). Materialübergreifende Analyse des GH 16 der Grotte de la Verpillière I in Germolles, Gemeinde Mellecey (Saône-etLoire, Frankreich). [Unpublished Bachelor's thesis]. Eberhard Karls Universität Tübingen.

Locht, J.-L., \& Antoine, P. (2001). Caractérisation techno-typologique et position chronostratigraphique de plusieurs industries à rares bifaces ou amincissements bifaciaux du Nord de la France. In D. Cliquet (Ed.), Les industries à outils bifaciaux du Paléolithique moyen d'Europe occidentale. Actes de la table-ronde internationale organisée à Caen (Basse-Normandie - France) - 14 et 15 octobre 1999. Études et Recherches Archéologiques de l'Université de Liège, Vol. 98 (pp. 129-134). Université de Liège.

Locht, J.-L., Hérisson, D., Goval, E., Cliquet, D., Huet, B., Coutard, S., Antoine, P., \& Feray, P. (2016). Timescales, space and culture during the Middle Palaeolithic in northwestern France. Quaternary International, 411/A, 129-148. https://doi.org/10.1016/j. quaint.2015.07.053

Mackay, A., Sumner, A., Jacobs, Z., Marwick, B., Bluff, K., \& Shaw, M. (2014). Putslaagte 1 (PL1), the Doring River, and the later Middle Stone Age in southern Africa's Winter Rainfall Zone. Quaternary International, 350, 43-58. https://doi.org/10.1016/j. quaint.2014.05.007

Méray, C. (1869). L'âge de la pierre à Germolles. Matériaux d'Archeólogie et d'Histoire par MM. les Archéologues de Saône-et-Loire et des Départements limitrophes, 1(6-7), 83-86.

Méray, C. (1876). Fouilles de la caverne de Germolles. Commune de Mellecey. Mémoires de la Société d'Histoire et d'Archéologie de Chalon-sur-Saône, 6, 251-266.

Mortillet, G. d. (1869). Essai d'une classification des cavernes et des stations sous abri fondée sur les produits de l'industrie humaine. In G. D. Mortillet (Ed.), Matériaux pour L'histoire primitive et naturelle de L'Homme et l'étude du sol, de la faune et de la flore qui s'y rattachent, Vol. 5 (p. 172-179). Reinwald.

Mortillet, G. d. (1873). Classification des diverses périodes de l'âge de la pierre. In G. D. Mortillet (Ed.), Compte Rendu du Congrès International d'Anthropologie et d'Archéologie Préhistorique. 6ième Session, Bruxelles, 1872 (pp. 432-444). Weissenbruch.

Müller-Beck, H. (1956). Das obere Altpaläolithikum in Süddeutschland. Ein Versuch zur ältesten Geschichte des Menschen, Vol. 1. Hamburg: Hamburger Buchdruckerei und Verlagsanstalt Auerdruck.

North Greenland Ice Core Project members. (2004). High-resolution record of Northern Hemisphere climate extending into the last 
interglacial period. Nature, 431, 147-151. https://doi.org/10.1038/ nature02805

Parriat, H. (1956). Une station moustérienne inédite. La Physiophile, 45, 9-16.

Pouliquen, C. (1982). Le Moustérien de La Roche à Saint-Martin-sousMontaigu (Saône-et-Loire). Collection Lènez au Musée Denon à Chalon-sur-Saône. Diplome d'Études Supérieures. Université de Bordeaux.

Pouliquen, C. (1983). Le Moustérien de La Roche à Saint-Martin-sousMontaigu (Saône-et-Loire) d'après la collection Lènez au Musée Denon à Chalon-sur-Saône. Revue Archéologique de l'Est et du Centre-Est Dijon, 133(3-4), 183-207.

Rademacher, C. (1911). Der Kartstein bei Eiserfey in der Eifel. Praehistorische Zeitschrift, 3(3-4), 201. https://doi.org/10.1515/ prhz.1911.3.3-4.201

Railsback, L. B., Gibbard, P. L., Head, M. J., Voarintsoa, N. R. G., \& Toucanne, S. (2015). An optimized scheme of lettered marine isotope substages for the last 1.0 million years, and the climatostratigraphic nature of isotope stages and substages. Quaternary Science Reviews, 111, 94-106. https://doi.org/10.1016/j.quascirev.2015.01.012

Richard, M., Falguères, C., Ghaleb, B., \& Richter, D. (2016). Résultats préliminaires des datations par ESR/U-Th sur émail dentaire, Grottes de la Verpillière I et II. In Floss, H., Hoyer, C. T., Frick, J. A., \& Herkert, K. (Eds.), Projet Collectif de Recherche - Le Paléolithique supérieur ancien en Bourgogne méridionale. Genèse, chronologie et structuration interne, évolution culturelle et technologique. Rapport annuel 2015 (pp. 11-23). Abteilung für Ältere Urgeschichte und Quartärökologie, Tübingen.

Richter, J. (1997). Sesselfelsgrotte III. Der G-Schichten-Komplex der Sesselfelsgrotte. Zum Verständnis des Micoquien. Quartär-Bibliothek 7. Saarbrückener Druckerei und Verlag.

Rots, V. (2010). Prehension and Hafting Traces on Flint Tools. A Methodology. Leuven University Press. https://doi.org/10.2307/j. ctt9qf05s

Rots, V. (2016). Projectiles and Hafting Technology. In R. Iovita, \& Sano, K. (Eds.), Multidisciplinary Approaches to the Study of Stone Age Weaponry. Vertebrate Paleobiology and Paleoanthropology (pp. 167-185). Springer. https://doi.org/10.1007/978-94-017-7602-8_12

Ruebens, K. (2012). From Keilmesser to Bout Coupé Handaxes: Macro-Regional Variability among Western European Late Middle Palaeolithic Bifacial Tools. [Unpublished Doctoral Dissertation]. University of Southampton.

Ruebens, K. (2013). Regional behaviour among late Neanderthal groups in Western Europe: A comparative assessment of late Middle Palaeolithic bifacial tool variability. Journal of Human Evolution, 65(4), 341-362. https://doi.org/10.1016/j.jhevol.2013.06.009

Schiller, J. (2018). Die paläolithische Freilandfundstelle Bissy-sur-Fley, La Clauzure. Ausgewählte Funde aus der Sammlung Jacques Daudey. [Unpublished Bachelor's thesis]. Eberhard Karls Universität Tübingen.

Slimak, L. (2004). Les dernières Expressions du Moustérien entre Loire et Rhône. [Unpublished Doctoral Dissertation]. Université de Provence.

Slimak, L. (2007). Le Néronien et la structure historique du basculement du Paléolithique moyen au Paléolithique supérieur en France méditerranéenne. Comptes Rendus Palevol, 6(4), 301-309. https://doi.org/10.1016/j.crpv.2007.02.004

Slimak, L. (2008). The Neronian and the historical structure of cultural shifts from Middle to Upper Palaeolithic in Mediterranean France. Journal of Archaeological Science, 35(8), 2204-2214. https:// doi.org/10.1016/j.jas.2008.02.005
Sollas, W. J. (1911). Ancient Hunters And their Modern Representatives (1st. edn). MacMillian and Co.

Soressi, M., Roussel, M. (2014). European Middle to Upper Paleolithic Transitional Industries: Châtelperronian. In C. Smith (Ed.), Encyclopedia of Global Archaeology (pp. 2679-2693). Springer. https:// doi.org/10.1007/978-1-4419-0465-2_1852

Uthmeier, T. (2004). Micoquien, Aurignacien und Gravettien in Bayern. Eine regionale Studie zum Übergang vom Mittel- zum Jungpaläolithikum. Archäologische Berichte 18. Deutschen Gesellschaft für Urund Frühgeschichte e.V.

Valoch, K. (1988). Die Erforschung der Kůlna-Höhle 1961-1976. Anthropos - Studien zur Anthropologie, Paläoethnologie, Paläanthropologie und Quartärgeologie, Vol. 24. Moravské Muzeum.

Veil, S., Breest, K., Höfle, H. C., Meyer, H. H., Plisson, H., Urban-Küttel, B., Wagner, G. A., \& Zöller, L. (1994). Ein mittelpaläolithischer Fundplatz aus der Weichsel-Kaltzeit bei Lichtenberg, Lkr. Lüchow-Dannenberg. Germania, 72(1), 1-66.

Würschem, H. (2015). Das Châtelperronien der Grotte de la Verpillière I (Saône-et-Loire, Frankreich). [Unpublished Bachelor's thesis]. Eberhard Karls Universität Tübingen.

Zöller, L., \& Schmidt, C. (2016). Germolles - Grotte de la Verpillière II GH 3 \& 4, Report on luminescence dating of cave sediments. In H. Floss, Hoyer, C. T., Frick, J. A., \& Herkert, K. (Eds.), Projet Collectif de Recherche - Le Paléolithique supérieur ancien en Bourgogne méridionale. Genèse, chronologie et structuration interne, évolution culturelle et technologique. Rapport annuel 2015 (pp. 45-49). Abteilung für Ältere Urgeschichte und Quartärökologie, Tübingen. 